\title{
Glycine Transporters Are Differentially Expressed among CNS Cells
}

\author{
Francisco Zafra, ${ }^{1}$ Carmen Aragón, ${ }^{1}$ Luis Olivares, ${ }^{1}$ Niels C. Danbolt, ${ }^{2}$ Cecilio Giménez, ${ }^{1}$ and Jon Storm- \\ Mathisen ${ }^{2}$ \\ "Centro de Biología Molecular "Severo Ochoa," Facultad de Ciencias, Universidad Autónoma de Madrid, E-28049 \\ Madrid, Spain, and ${ }^{2}$ Anatomical Institute, University of Oslo, Blindern, N-0317 Oslo, Norway
}

\begin{abstract}
Glycine is the major inhibitory neurotransmitter in the spinal cord and brainstem and is also required for the activation of NMDA receptors. The extracellular concentration of this neuroactive amino acid is regulated by at least two glycine transporters (GLYT1 and GLYT2). To study the localization and properties of these proteins, sequence-specific antibodies against the cloned glycine transporters have been raised. Immunoblots show that the 50-70 $\mathrm{kDa}$ band corresponding to GLYT1 is expressed at the highest concentrations in the spinal cord, brainstem, diencephalon, and retina, and, in a lesser degree, to the olfactory bulb and brain hemispheres, whereas it is not detected in peripheral tissues. Pre-embedding light and electron microscopic immunocytochemistry show that GLYT1 is expressed in glial cells around both glycinergic and nonglycinergic neurons except in the retina, where it is expressed by amacrine neurons, but not by glia. The expression of a 90-110 kDa band corresponding to GLYT2 is restricted to the spinal cord, brainstem, and cerebellum; in addition, very low levels occur in the diencephalon. GLYT2 is found in presynaptic elements of neurons thought to be glycinergic. However, in the cerebellum, GLYT2 is expressed both in terminal boutons and in glial elements. The physiological consequences of the regional and cellular distributions of these two proteins as well as the posslbllity of the existence of an unidentified neuronal form of GLYT1 are discussed.
\end{abstract}

[Key words: neurotransmitter transport, glycine, antibodies, immunocytochemistry, glia, retina]

Glycine is thought to have two roles in neurotransmission. In spinal cord and brainstem it is an important inhibitory neurotransmitter. In these regions, glycine acts on the strychnine-sensitive glycine receptor, a pentameric chloride channel protein composed of $\alpha$ and $\beta$ subunits as well as a peripheral membrane protein, named gephyrin (reviewed by Langosch et al., 1990).

Received Nov. 4, 1994; revised December 20, 1994; accepted Dec. 30, 1994.

We thank Drs. K. E. Smith and R. L. Weinshank from Synaptic Pharmaceutical Corporation for providing the $\mathrm{rB20a}$ clone (GLYT1) and Di. N. Nelson from Roche Institute for Molecular Biology for providing the NTT1I clone (GLYT2). We also acknowledge the expert comments of Drs. K. K. Osen and $O$. P. Ottersen. The tcchnical assistance of E. Nuñcz and A. T. Bore is gratefully acknowledged. Supported by the Spanish DGICYT (PB92-0131), Norwegian Research Council, European Union BIOMED program (BMHI-CT93-1110), Boehringer Ingelheim España, S.A., and an institutional grant from the Fundación Ramón Areces. F.Z. was supported in part by an EMBO short-term fellowship.

Correspondence should be addressed to Dr. Francisco Zafra at the above address.

Copyright 1995 Society for Neuroscience $0270-6474 / 95 / 153952-18 \$ 05.00 / 0$
In addition, glycine is a coagonist with glutamate on postsynaptic $N$-methyl-D-aspartate (NMDA) receptors (Johnson and Ascher, 1987).

The reuptake of neurotransmitter amino acids into presynaptic nerve endings or the neighboring fine glial processes provides a way of clearing the extracellular space of neuroactive substances, and so constitutes an efficient mechanism by which the synaptic action can be terminated (Kanner and Schuldiner, 1987). Specific high-affinity transport systems have been identified in nerve terminals and glial cells for several amino acid neurotransmitters, including glycine (Johnston and Iversen, 1971; Logan and Snyder, 1972; Kuhar and Zarbin, 1978; Zafra and Giménez, 1986; Fedele and Foster, 1992).

In the past few years, some of the neurotransmitter transporters have been purified from mammalian brain (Radian et al., 1986; Danbolt et al., 1990; López-Corcuera et al., 1991) and, more recently, cDNA clones encoding transporters for GABA, catecholamines, serotonin, glycine, proline, and glutamate have been isolated (Guastella et al., 1990, 1992; Blakely et al., 1991; Hoffman et al., 1991; Kilty et al., 1991; Pacholczyk et al., 1991; Shimana et al., 1991; Usdin et al., 1991; Borden et al., 1992; Fremau et al., 1992; Giros et al., 1992; Kanai and Hediger, 1992; Pines et al., 1992; Liu et al., 1992, 1993; Smith et al., 1992; Storck et al., 1992). On the basis of the cDNA sequences, these proteins have now been classified into two families (Uhl and Hartig, 1992; Amara and Kuhar, 1993; Kanai et al., 1994): the sodium and chloride-dependent neurotransmitter transporter family, including transporters for GABA, catecholamines, serotonin, proline, and glycine; and the glutamate transporter family. To date, two different glycine transporters have been cloned. A glycine transporter (GLYT1) (Smith et al., 1992; Guastella et al., 1992; Liu et al., 1992), which presents three isoforms produced by alternative splicing and/or alternative promoter usage (Borowski et al., 1993; Kim et al., 1994; Adams et al., 1995); these isoforms differs in the amino-termini and are termed GLYT1a, GLYT1b, and GLY'IC (Liu et al. 1993; Kim et al., 1994; Adams et al., 1995). More recently, the existence of a second glycine transporter (GLYT2) has been reported (Liu et al., 1993). GLYT2 is present selectively in the brainstem and spinal cord (Liu et al., 1993; Zafra, Gomeza, Olivares, Aragón, and Giménez, unpublished observations), areas of the CNS where strychnine-sensitive glycine receptors are more abundant.

In this study we describe immunocytochemically and quantitatively the regional and cellular localizations of GLYT1 and GLYT2, using antibodies raised against specific sequences of the two proteins. The comparative distributions of the corresponding 
mRNAs will be analyzed in a separate report (Zafra, Gomeza, Olivares, Aragón, and Giménez, unpublished observations).

\section{Materials and Methods}

\section{Materials}

Bovine serum albumin (BSA), ethylene glycol-bis-aminoethyl ether $N, N, N^{\prime}, N^{\prime}$-tetraacetic acid (EGTA), $N$-2-hydroxyethylpiperazine- $N^{\prime}$-2-ethane sulfonic acid (HEPES), keyhole limpet hemocyanin (KLH), ovalbumin, diaminobenzidine, phenylmethanesulfonyl fluoride (PMSF), Triton X-100, Trizma base, glutathione, and Tween 20 were from Sigma (St. Louis, MO). Dextran-70, Sephadex G-50 fine, pGEX2, Glutathione Sepharose 4B, and Protein A-Sepharose Fast Flow were from Pharmacia (Uppsala, Sweden). Isopropylthiogalactoside, EcoRI, BamHI, and T4 ligase were from Boehringer-Mannheim (Germany). Taq polymerase was from Perkin Elmer Cetus. Freund's adjuvant was from Difco (Detroit, MI). Affi-Gel 15 ( $\mathrm{N}$-hydroxysuccinimide esters of cross-linked agarose) and nitrocellulose sheets were from Bio-Rad (Richmond, CA). Newborn calf serum was from GIBCO (Paisley, Scotland). N,N'-Methylene-bisacrylamide, acrylamide, ammonium persulfate, and TEMED were from Promega (Madison, WI). Standard proteins for sodium dodecyl sulfatepolyacrylamide gel electrophoresis (SDS-PAGE) (Rainbow markers), biotinylated donkey anti-rabbit Ig, biotinylated sheep anti-mouse Ig streptavidin-biotinylated horseradish peroxidase complex were from Amersham Corporation (Buckinghamshire, UK). Glutaraldehyde, EM grade, was from TAAB (Reading. UK), and Durcupan ACM from Fluka (Buchs, Switzerland). Other reagents were analytical grade.

\section{Methods}

Preparation of glutathione S-transferase-glycine transporter fusion proteins. The 228 base pair (bp) of the carboxyl terminus of GLYTI and the 570 bp of the amino terminus of GLYT2 were synthesized by polymerase chain reaction using as templates the full length clones kindly provided by Drs. K. E. Smith and R. L. Weinshank (Synaptic Corporation) and Dr. N. Nelson (Roche Institute), respectively. The specific oligonucleotide primers were as follows: for GLYT1 the forward primer was CCGGGATCCCAGCTCTGCCGCACAGAT and the reverse CCGGGAATTCATATCCGGGAGTCCTG; for GLYT2 the forward primer was CCGGGATCCATGGATTGCAGTGCTCCC and the reverse CCGAATTCTCATCTGGCCTTATTCTCATC. Each primer consist of 18-21 bases of the specific GLYT1 or GLYT2 sequence plus a 9-oligomer nucleotide sequence added to the $5^{\prime}$ end of each. The latter included a $B a m \mathrm{HI}$ restriction site in the forward primers and a $E c o$ RI restriction site in the reverse primers. The $B a m H I$ site is placed such that the inserts were in the correct reading frame after insertion in the $B a m \mathrm{HI} / E(o \mathrm{RI}$ sites of the pGEX-2 plasmid. These restriction sites are located in the carboxyl terminus of the glutathione S-transferase (GST). After ligation of the inserts to pGEX-2, Escherichia coli XL-1 blue transformants were selected in LB ( $10 \mathrm{gm} /$ liter bacto-tryptone, $5 \mathrm{gm} /$ liter bacto-yeast extract, $10 \mathrm{gm} /$ liter $\mathrm{NaCl}, \mathrm{pH} 7.0$ )-agar plates containing $50 \mu \mathrm{g} / \mathrm{ml}$ of ampicillin. Individual colonics containing the pGEXGLYT1 or pGEX-GLYT2 were identified and sequenced using standard procedures. The expression of the fusion protein was induced by isopropylthiogalactoside (IPTG) as follows: bacteria were grown overnight at $37^{\circ} \mathrm{C}$ in $50 \mathrm{ml}$ of LB medium containing $50 \mu \mathrm{g} / \mathrm{ml}$ of ampicillin. Afterward, bacteria were diluted with $200 \mathrm{ml}$ of the same growth medium and incubated at $37^{\circ} \mathrm{C}$ for $1 \mathrm{hr}$. Induction was carried out for $5 \mathrm{hr}$ by adding IPTG ( $1 \mathrm{~mm}$ final concentration). The induced bacteria were collected by centrifugation resuspended in phosphate buffered saline (PBS) medium (137 mM NaCl, $0.9 \mathrm{~mm} \mathrm{CaCl}, 2.68 \mathrm{~mm} \mathrm{KCl}, 1.47 \mathrm{~mm}$ $\left.\mathrm{KH}_{2} \mathrm{PO}_{4}, 0.49 \mathrm{mM} \mathrm{MgCl}, 7.37 \mathrm{~mm} \mathrm{Na} \mathrm{HPO}_{4}, \mathrm{pH} 7.4\right)$ containing 10 $\mathrm{mM}$ EDTA, $0.2 \mathrm{mg} / \mathrm{ml}$ lysozyme, and $1 \mathrm{mM}$ PMSF and lysed by sonication. The lysate was cleared by centrifugation and the supernatant was passed through a Glutathione Sepharose $4 \mathrm{~B}$ column. The fusion protcin was cluted with $10 \mathrm{~mm}$ glutathione in $50 \mathrm{~mm}$ Tris-IICl, pII 7.5 .

Coupling of synthetic peptide to carrier protein. The peptide IVGSNGSSRLQDSRI corresponding to amino acids 623-638 of GLYT1 was coupled to carrier protein (ovalbumin or KLH) with glutaraldehyde as described (Lehre et al., 1995). The peptide-KLH conjugate was used for immunization (see below), while the peptide-ovalbumin conjugate was used for testing of antisera as described (Lehre et al., 1995).

Immunization. Immunization was carried out in MDL New Zealand rabbits (Navarra, Spain). The above fusion proteins $(100 \mu \mathrm{g})$ or conjugate peptide $(50 \mu \mathrm{g})$ were mixed with $0.4 \mathrm{ml}$ of water, emulsified
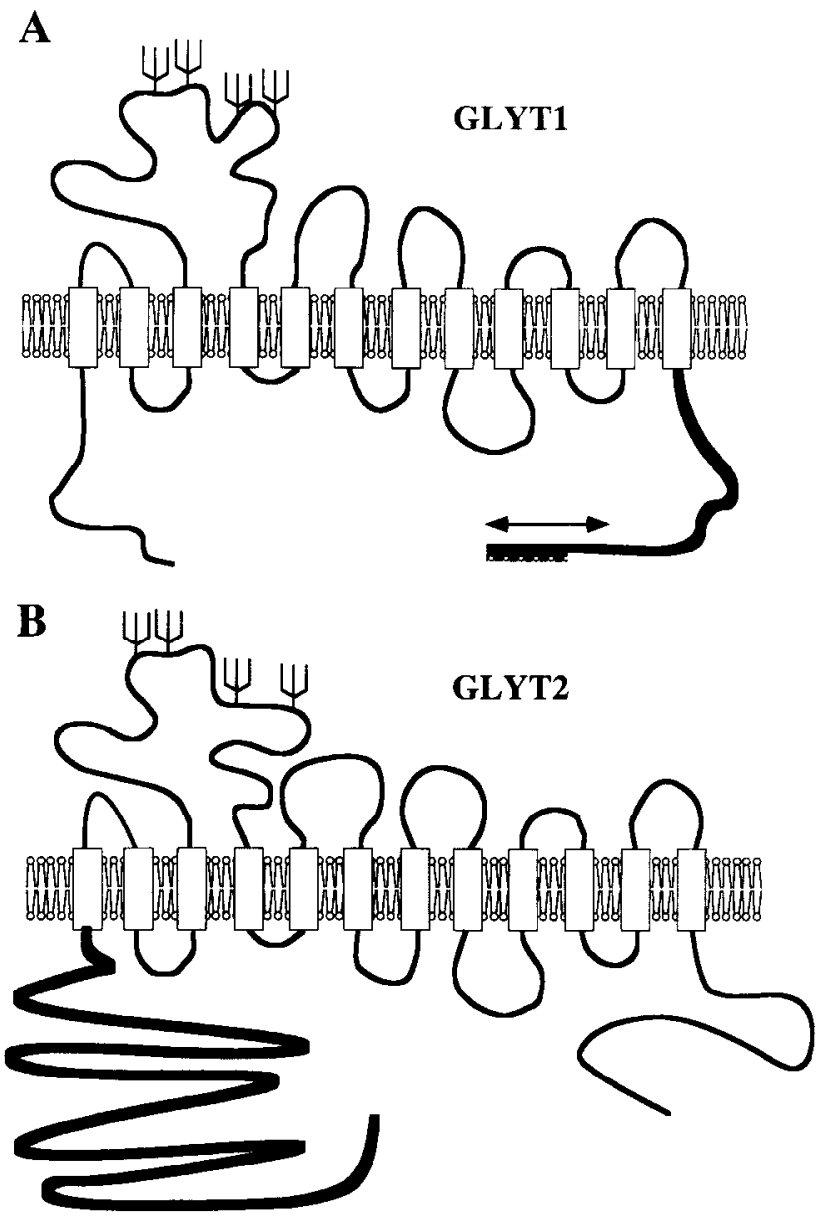

Figure I. The oligopeptide sequences of the glycine transporters that have been used for production of antibodies correspond to the 76 amino acids of the carboxyl-terminus of GLYT1 (anti-GLYT1-f) (black thick line in $A$ ), or to the 15 amino acids of the same carboxyl terminus (antiGLYT1-p) (decorated thick line in A), or to the 193 amino acids of the amino-terminus of GLYT2 (anti-GLYT2-f) (thick line in B). The epitopes recognized by anti-GLYT1-f have been mapped into the last 25 amino acids of the carboxyl-terminus of GLYTI (double arrow in A) There is no homology between GLYT1 and GLYT2 in the regions to which antibodies were raised.

with $0.5 \mathrm{ml}$ Freund's complete adjuvant. Rabbit number 176 received GST-GLYT1, number 218 was injected with GST-GLYT2 and number 623 with KLH-peptide. The rabbits were reimmunized every second week (for fusion proteins) or every month (for peptide) as above, but using Freund's incomplete adjuvant

Immobilization of fusion proteins, carrier proteins, and peptide on agarose. Peptide ( $1 \mathrm{mg}$ ) or fusion proteins (1 mg) were dissolved in Na-HEPES buffer, $\mathrm{pH} 8.0$. and coupled to Affi-Gel $15(5 \mathrm{ml}$ gel) following the manufacturer's instructions. KLH (500 mg) or $10 \mathrm{mg}$ GST were immobilized (as above) on $25 \mathrm{ml}$ Affi-Gel 15. The immobilized KLH was treated with glutaraldehyde as described (Lehre et el., 1995).

Antibody purification. The purification of antibodies was performed as described (Lehre et al., 1995). The anti-fusion protein antisera (antiGLYT1-f, and anti-GLYT2-f) were absorbed with immobilized GST, concentrated on a protein A-Sepharose column, and finally affinity purified on a column with immobilized fusion protein. The anti-peptide antiserum (anti-GLYTI-p) was first affinity purified on a column with immobilized glutaraldehyde-treated KLH and finally concentrated on a protein A-Sepharose column. BSA $(1 \mathrm{mg} / \mathrm{ml})$ and $\mathrm{NaN}_{3}(1 \mathrm{mg} / \mathrm{ml})$ were added to stabilize the antibodies. Anti-peptide antibodies and antibodies from rabbit 176 (anti-GLYT1-f) yielded the same results in immunocytochemistry experiments. Antibodies from other rabbits were obtained, but the quality of them was not satisfactory. For instance, antibodies from rabbit 177 (immunized as 176) stained the same structures 


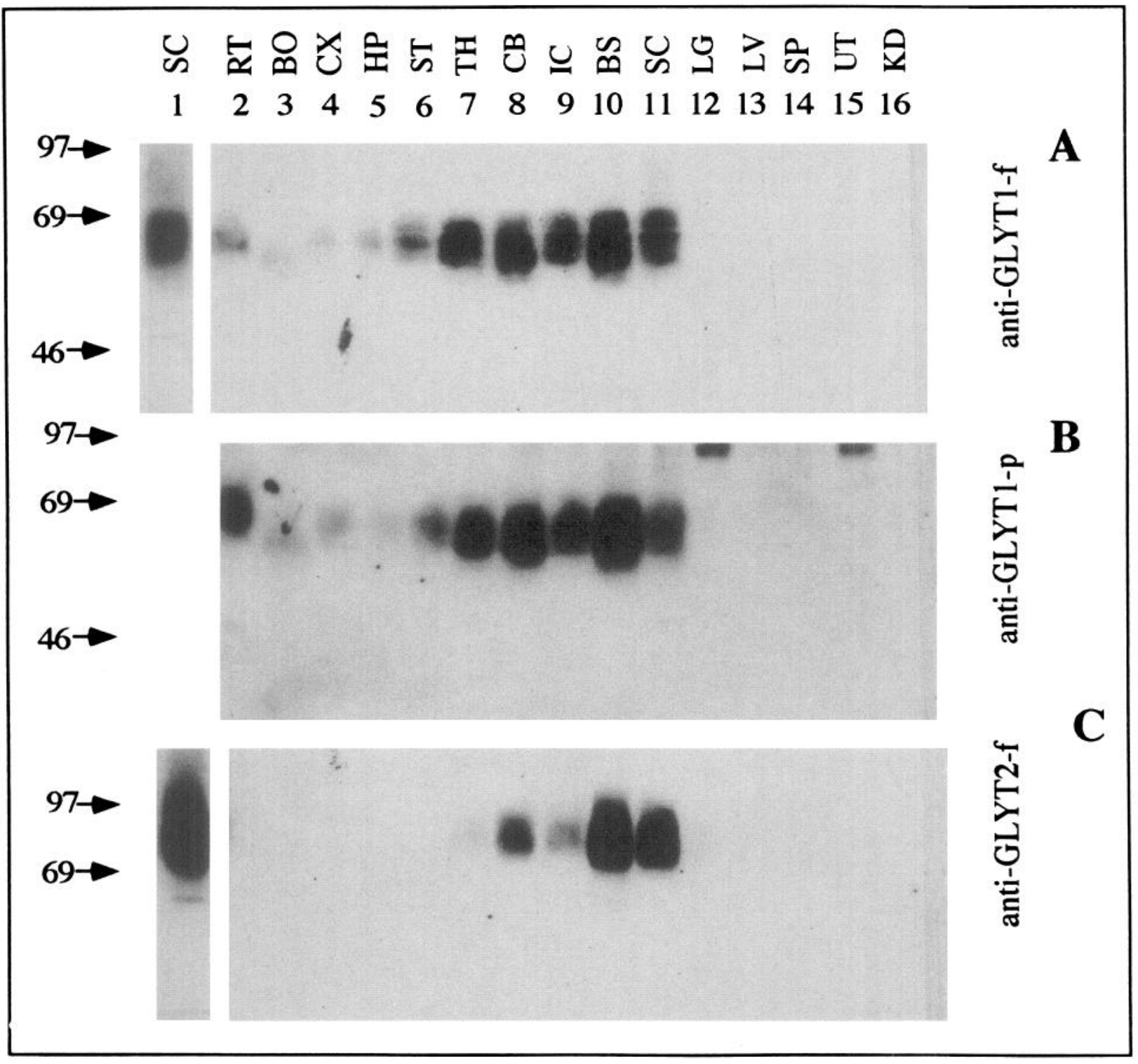

Figure 2. Immunoblot (Western blot) of crude SDS extracts from different brain areas subjected to SDS-PAGE ( $30 \mu \mathrm{g}$ protein/lane) and reacted with anti-GLYT1-f $(A)$, anti-GLYT1-p $(B)$, or anti-GLYT2-f $(C)$. Antibodies were used as crude serum (1:250) (lane $I)$ or affinity purified $(0.25$ $\mu \mathrm{g} / \mathrm{ml}$ ) (lanes 2-16). Bands were visualized with the enhanced chemiluminescence method (ECL). Regions dissected: $R T$, retina; $B O$, olfactory bulb; $C X$, cerebral cortex; $H P$, hippocampus; $S T$, corpus striatum; $T H$, thalamus/hypothalamus; $C B$, cerebellum; $I C$, inferior colliculus; $B S$, brainstem; $S C$, spinal cord; $L G$, lung; $L V$, liver; $S P$, spleen; $U T$, uterus; $K D$, kidney. Molecular mass markers are indicated (kDa).

as those from rabbit 176 but, in addition, a strong cytoplasmic staining that could not be interpreted. Because of this, antibodies from rabbit 177 were discarded. For GLYT2, antibodies from rabbits 218 and 219 (immunized as 218) produced the same staining pattern, but those from rabbit 219 stained in addition some cell nuclei. Thus, only antibodies from rabbit 218 (anti-GLYT2-f) were further used.

Preparation of SDS extracts. SDS extracts from whole rat brains or specific regions were prepared by homogenizing and solubilizing the tissue in PBS with SDS $(10 \mathrm{mg} / \mathrm{ml})$ and $1 \mathrm{~mm}$ PMSF, and removing unsolubilized material by centrifugation $\left(50,000 \times \mathrm{g}, 10 \mathrm{~min}, 10^{\circ} \mathrm{C}\right)$.

Electrophoresis and blotting. SDS-PAGE was done in the presence of 2-mercaptoethanol. The gels were run slowly (over night) at constant current starting at $30 \mathrm{~V}$. After electrophoresis, samples were transferred by electroblotting onto a nitrocellulose membrane in a semidry electrob- lotting system $(\mathrm{LKB})$ at $1.2 \mathrm{~mA} / \mathrm{cm}^{2}$ for $2 \mathrm{hr}$. The transfer buffer consisted of $192 \mathrm{~mm}$ glycine and $25 \mathrm{~mm}$ Tris- $\mathrm{HCl}, \mathrm{pH} 8.3$. Nonspecific protein binding to the blot was blocked by the incubation of the filter with $3 \%$ nonfat milk protein in $10 \mathrm{~mm}$ Tris- $\mathrm{HCl}, \mathrm{pH} 7.5,150 \mathrm{~mm} \mathrm{NaCl}$ for $4 \mathrm{hr}$ at $25^{\circ} \mathrm{C}$. The blot was then probed with the indicated dilutions of crude antisera or purified antibodies overnight at $4^{\circ} \mathrm{C}$. After washing, blots were then probed with an anti-rabbit IgG peroxidase linked, and bands were visualized with the enhanced chemoluminescent detection method (ECL) and quantified by densitometry (Molecular Finamics IMAGE QUANT version 3.0).

Protein determination. Protein was determined (Lowry et al., 1951) with bovine serum albumin as a standard. Protein in purified antibody solutions was determined spectrophotometrically at $280 \mathrm{~nm}$ using bovine IgG as a standard.

Figure 3. Immunocytochemical localization of GLYT1 $(A$ and $B)$ and GLYT2 $(C)$ in closely spaced parasagittal sections of rat brain. Sections $(40 \mu \mathrm{m})$ were incubated with $0.5 \mu \mathrm{g} / \mathrm{ml}$ of anti-GLYT1-f $(A)$, or $1.5 \mu \mathrm{g} / \mathrm{ml}$ of anti-GLYT1-p $(B)$, or $0.5 \mu \mathrm{g} / \mathrm{ml}$ of anti-GLYT2-f $(C)$ in the presence 

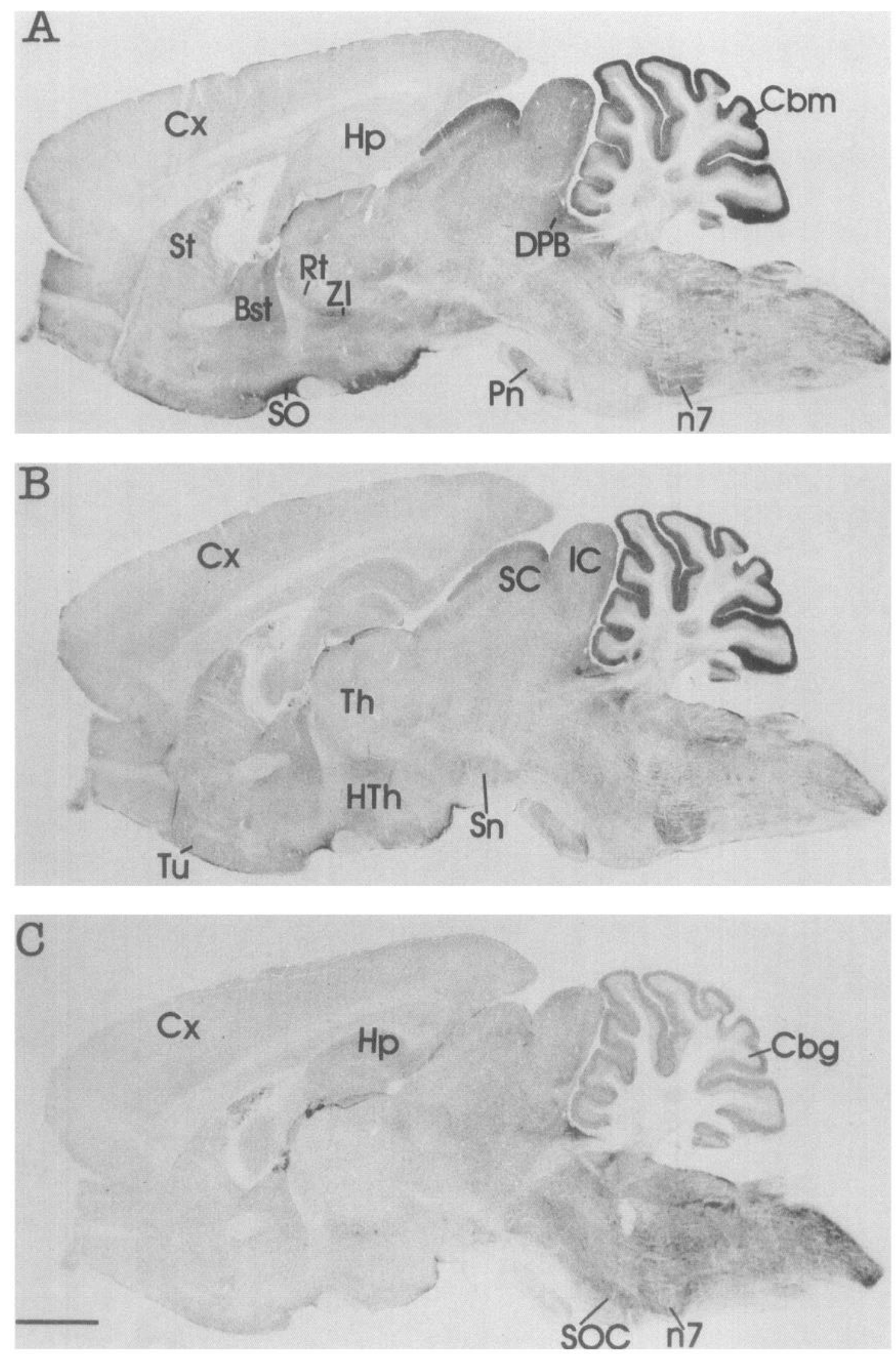

of $0.1 \%$ Triton X-100. Abbreviations: $B s t$, bed nucleus of stria terminalis; $C x$, cortex; $C b g$, granular layer of the cerebellum; $C b m$, molecular layer of the cerebellum; $D P B$, dorsal parabrachial area; $H p$, hippocampus; $H T h$, hypothalamus; $I C$, inferior colliculus; $n 7$, motor facial nucleus; $P n$, pontine nuclei; $R t$, reticular thalamic nucleus; $S C$, superior colliculus; $S n$, substantia nigra; $S O$, supraoptic nucleus; $S O C$, superior olivary complex; $S t$, striatum; Th, thalamus; $T u$, olfactory tubercle; $Z I$, zona incerta. Scale bar, $2 \mathrm{~mm}$. 
Table 1. Distribution of glycine transporters in rat CNS

\begin{tabular}{|c|c|c|}
\hline Area & GLYT1 & GLYT2 \\
\hline Retina & $t+t$ & nd \\
\hline \multicolumn{3}{|l|}{ Olfactory system } \\
\hline Periglomerular & $++t$ & nd \\
\hline Internal granular layer & nd & nd \\
\hline Mitral cell layer & + & nd \\
\hline Anterior olfactory nu & + & nd \\
\hline Olfactory tubercle & + & nd \\
\hline Cortex & + & nd \\
\hline \multicolumn{3}{|l|}{ Basal nuclei } \\
\hline Accumbens nu & + & nd \\
\hline Caudate putamen & ++ & nd \\
\hline Subthalamic nu & $+t$ & nd \\
\hline \multicolumn{3}{|l|}{ Septum } \\
\hline Lateral septum & + & nd \\
\hline Diagonal band & + & nd \\
\hline \multicolumn{3}{|l|}{ Hippocampus } \\
\hline CAl-CA4 & ++ & nd \\
\hline Dentate gyrus & ++ & nd \\
\hline \multicolumn{3}{|l|}{ Thalamus } \\
\hline Posterior thal nu & + & nd \\
\hline Ventrolateral thal nu & + & nd \\
\hline Anteroposterior thal nu & ++ & nd \\
\hline Laterodorsal thal nu & ++ & nd \\
\hline Ventroposterior thal nu & ++ & nd \\
\hline Reticular thal nu & +++ & nd \\
\hline Zona incerta & +++ & + \\
\hline Hypothalamus & +++ & nd \\
\hline \multicolumn{3}{|l|}{ Substantia nigra } \\
\hline Reticular & ++ & + \\
\hline Compact & $+t+$ & + \\
\hline Superior colliculus & ++++ & + \\
\hline Inferior colliculus & +++ & ++ \\
\hline \multicolumn{3}{|l|}{ Pons-Medulla } \\
\hline \multicolumn{3}{|l|}{ Superior olivary complex } \\
\hline Lateral superior olive & +++ & +++ \\
\hline Medial nu trapezoid body & +++ & + \\
\hline Medial superior olive & ++ & + \\
\hline Superior paraolivary nu & ++ & ++++ \\
\hline Periolivary region & $+t+$ & +++ \\
\hline Cochlear nuclei & ++++ & +++ \\
\hline Lateral lemniscus nuclei & ++ & +++ \\
\hline Cuneate nu & +++ & ++ \\
\hline Gracile nu & +++ & ++ \\
\hline Spinal trigeminal nu & +++ & +++ \\
\hline Solitary tract nuclei & +++ & + \\
\hline Vestibular nuclei & +++ & +++ \\
\hline Facial nu & +++ & +++ \\
\hline Motor trigeminal nu & +++ & +++ \\
\hline Dorsal motor nu vagus & $++t$ & +++ \\
\hline Oculomotor nu & +++ & + \\
\hline Pontine reticular nuclei & $t+t$ & ++ \\
\hline Parvocellular reticular nu & +++ & +++ \\
\hline Gigantocellular reticular nu & +++ & +++ \\
\hline Lateral reticular nu & +++ & +++ \\
\hline Medullary reticular nuclei & +++ & +++ \\
\hline Locus ceruleus & +++ & ++ \\
\hline Raphe nuclei & +++ & ++ \\
\hline
\end{tabular}

Table 1. Continued

\begin{tabular}{lll} 
Area & GLYT1 & GLYT2 \\
\hline Pontine nuclei & +++ & + \\
Tegmental nuclei & +++ & + \\
Inferior olive & ++++ & nd \\
Central gray & +++ & + \\
Dorsal parabrachial area & ++++ & +++ \\
Cerebellum & & \\
Molecular cell layer & ++++ & + \\
Purkinje cell layer & ++ & + \\
Granule cell layer & ++ & ++ \\
Cerebellar nuclei & +++ & ++ \\
Spinal cord & & +++ \\
Gray matter & ++++ & ++ \\
White matter & ++ &
\end{tabular}

Sections $(40 \mu \mathrm{m})$ were incubated with $1 \mu \mathrm{g} / \mathrm{ml}$ anti-GLYT1-f, or $0.8 \mu \mathrm{g} / \mathrm{m}$ anti-GLYT2-f in the absence of Triton X-100. Relative staining intensities were estimated by microscopic examination of successive coronal sections; nd, not detected; + , low; ++ , medium; +++ , high; ++++ , very high. nu, nucleus; thal, thalamic; CA1-CA4, hippocampal subfields.

Immunocytochemistry. Three rats (Wistar strain, Møllegaard Hansen, Denmark) were deeply anesthetized with pentubarbilal (100 $\mathrm{mg} / \mathrm{kg})$ and perfused through the left ventricle-aorta with a fixative solution of formaldehyde/picric acid/glutaraldehyde $(4 \% / 0.2 \% / 0.05 \%)$ in $0.1 \mathrm{M}$ sodium phosphate pH 7.4 (Stefanini et al., 1967) $(500 \mathrm{ml}$, room temperature), preceded by a brief flush (10-15 sec) of Dextran-70 (MW 70,000;20 $\mathrm{mg} / \mathrm{ml}$ ) in the same buffer without fixative. The right atrium was cut open at the start of the perfusion. The perfusion liquids were delivered by a peristaltic pump at $50 \mathrm{ml} / \mathrm{min}$, starting within $20 \mathrm{sec}$ after thoracotomy. The brains were postfixed (overnight) in the same fixative. The tissue was stored at $4^{\circ} \mathrm{C}$ in a storage solution consisting of 1 part fixative and 9 parts $0.1 \mathrm{M}$ sodium phosphate until it was processed for pre-embedding light and electron microscopic immunocytochemistry. The fixative was chosen because it gives a good compromise between preservation of antigenicity and ultrastructure (Somogyi and Takagi, 1982). The aldehydes were freshly added, formaldehyde freshly depolymerized from parafonmaldehyde.

Vibratome sections $\left(40 \mu \mathrm{m}\right.$ thick) were cut $\left(4-10^{\circ} \mathrm{C}\right)$ and stored $\left(4^{\circ} \mathrm{C}\right.$, $12 \mathrm{hr}$ to 3 weeks) in $0.1 \mathrm{M}$ sodium phosphate with $\mathrm{NaN}_{3}(0.2-1 \mathrm{mg} / \mathrm{ml})$. Then the sections were rinsed in $0.1 \mathrm{M}$ sodium phosphate, incubated ( 30 $\min )$ in $1 \mathrm{M}$ ethanolamine with $0.1 \mathrm{M}$ sodium phosphate, washed $(3 \times 1$ min) in buffer $\mathrm{A}(0.135 \mathrm{M} \mathrm{NaCl}, 0.01 \mathrm{M}$ sodium phosphate), incubated in buffer $\mathrm{B}(0.3 \mathrm{M} \mathrm{NaCl}, 0.1 \mathrm{M}$ Tris- $\mathrm{HCl} \mathrm{pH} 7.4)$ with $10 \%(\mathrm{v} / \mathrm{v})$ newborn calf serum and $\mathrm{NaN}_{3}(1 \mathrm{mg} / \mathrm{ml})$, and then incubated $\left(12-48 \mathrm{hr}, 4^{\circ} \mathrm{C}\right.$ or room temperature) with antibodies $(0.3-3 \mu \mathrm{g} / \mathrm{ml})$ diluted in buffer $C$. (buffer B with $1 \%$ newborn calf serum). The sections were washed $(3 \times$ $1 \mathrm{~min}$ and $2 \times 10-20 \mathrm{~min}$ ) in buffer $\mathrm{C}$, incubated ( $1 \mathrm{hr}$ ) with biotinylated donkey anti rabbit $\mathrm{Ig}(1: 100)$ in buffer $\mathrm{C}$, washed $(3 \times 1 \mathrm{~min}$ and $2 \times$ $15 \mathrm{~min}$ ) in buffer $\mathrm{C}$, incubated ( $1 \mathrm{hr})$ with streptavidin-biotinylated horseradish peroxidase complex in buffer $\mathrm{C}$, and washed $(3 \times 1 \mathrm{~min}$ and $2 \times$ 15 mini) in buffer $C$. Then the sections were washed $(3 \times 1$ min) in buffer $A$, incubated for 6 min in $0.1 \mathrm{M}$ sodium phosphate with $\mathrm{H}_{2} \mathrm{O}_{2}(0.1 \mathrm{mg} /$ $\mathrm{ml})$ and diaminobenzidine $(0.5 \mathrm{mg} / \mathrm{ml})$ after $6 \mathrm{~min}$ of preincubation in sodium phosphate/diaminobenzidine without $\mathrm{H}_{2} \mathrm{O}_{2}$, and finally the reaction was stopped with 0.1 M sodium phosphate $(2 \times 3 \mathrm{~min})$. Triton X-100 $(0.1 \%)$ was included only when stated. For light microscopy, vibratome sections were mounted in glycerol-gelatin. Brain areas were identified referring to the atlas of Paxinos and Watson (1982). For electron microscopy, the sections were treated with osmium $(30-45 \mathrm{~min}, 10 \mathrm{mg} / \mathrm{ml}$ in $0.1 \mathrm{M}$ sodium phosphate), washed $(3 \times 1 \mathrm{~min})$ in $0.1 \mathrm{M}$ sodium phosphate, dehydrated in graded ethanols $(50 \%, 70 \%, 80 \%, 96 \% 1 \times 5 \mathrm{~min}$ and $100 \% 3 \times 10 \mathrm{~min})$ and propylene oxide $(2 \times 5 \mathrm{~min})$, and embedded in Durcupan ACM. Ultrathin sections were cut at right angles to the thick $(40 \mu \mathrm{m})$ ones in order to be able to study the parts of the tissue that had been in immediate contact with the reagents. The sections were contrasled (10 $\mathrm{mg} / \mathrm{ml}$ uranyl acetate $10-15 \mathrm{~min}$ and $3 \mathrm{mg} / \mathrm{ml} \mathrm{Pb}$-citrate $1-2 \mathrm{~min}$ ) and examined in a Philips CM10 electron microscope.

For control, primary antibodies were substituted by preimmune $\lg G$, or immune IgG freed of specific IgG by immunosorption with peptide of 

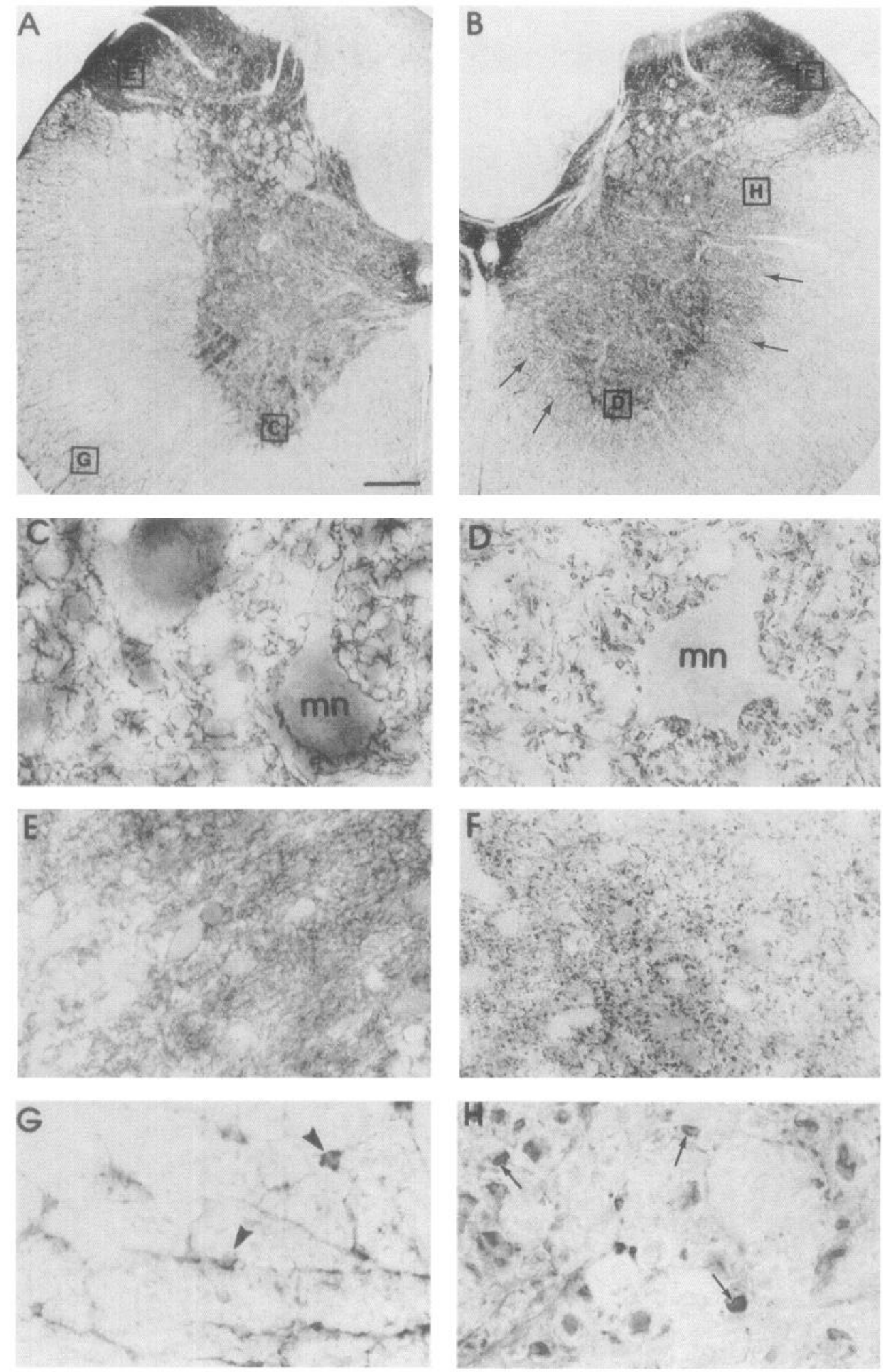

Figure 4. Localization of GLYT1 and GLYT2 in the rat cervical spinal cord. For this and the subsequent figures, sections $(40 \mu \mathrm{m})$ were incubated with $1 \mu \mathrm{g} / \mathrm{ml}$ anti-GLYT1-f $(A)$, or $0.8 \mu \mathrm{g} /$ $\mathrm{ml}$ anti-GLYT2-f $(B)$ in the absence of Triton $\mathrm{X}-100$. The boxed areas are shown at higher magnification in $C, D$ (ventral horn), $E, F$ (dorsal horn), $G$, and $H$ (white matter). $E$ is mirror image of $A$. Note GLYT1 glial staining around neuronal processes and motoneurons $(m n$ in $C$ ) in the ventral horn, around processes and cell bodies of the dorsal horn $(E)$ and inside cell bodies (arrowheads in $G$ ) and processes of glial cells in the white matter $(G)$. The shadows over $m n$ in $C$ are due to stained structures on the other side of the section. GLYT2 stained structures correspond to large size terminals around motoneurons $(\mathrm{mn}$ in $\mathrm{D})$, small size terminal in the dorsal horn $(F)$, and to transversally cut axons (arrows in $H$ ) mainly located in the areas of propriospinal axons in the lateral and ventral funiculus (arrows in $B$ ). Scale bar: $0.25 \mathrm{~mm}$ for $A$ and $B, 15 \mu \mathrm{m}$ for $C-F$, $25 \mu \mathrm{m}$ for $G, 12 \mu \mathrm{m}$ for $H$. fusion protein. Immunosorption of antibodies was performed for $4 \mathrm{hr}$ with the corresponding fusion protein or peptide immobilized on agarose (as indicated above) after the antibodies had been diluted to the final working concentration in buffer $\mathrm{C}$. These controls resulted in complete suppression of staining of tissue sections with the antibodies used in the present study (GLYT1-f, GLYT1-p, GLYT2-f). Absorption of the antibodies raised to fusion proteins by aldehyde-treated protein (Danbolt et al., 1992) resulted in no change of staining of brain sections and was therefore not performed routinely.

\section{Results}

Regional immunochemical quantitation of glycine transporters Antibodies were raised against fusion proteins expressed in Escherichia coli by using the expression vector pGEX2. Fusion proteins containing either the 76 amino acids of the carboxyl terminus of GLYT1 or the 193 amino acids of the amino terminus of GLYT2 were purified and used for production of an- 

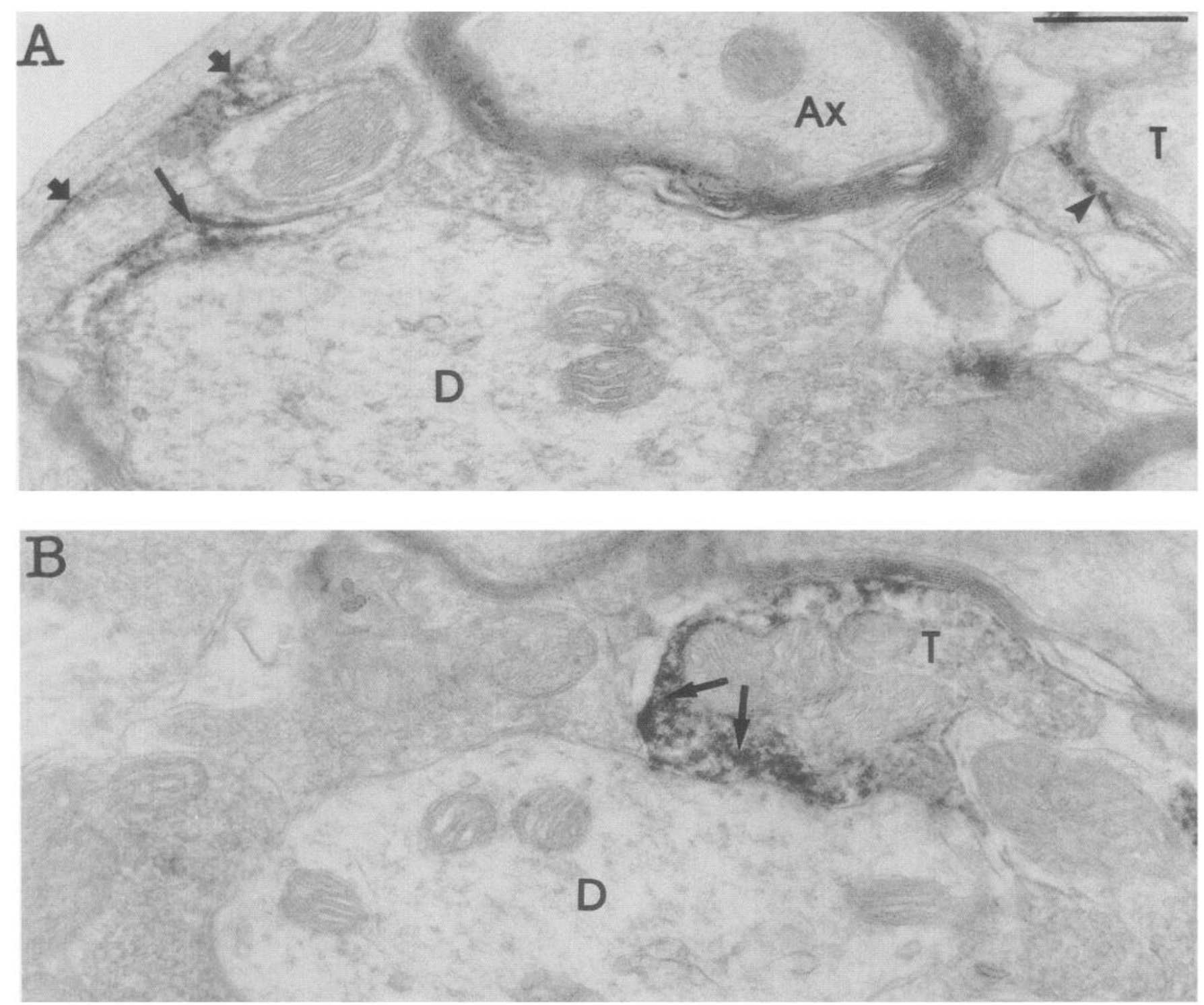

Figure 5. Electron micrographs of distribution of immunoreactivity for GLYT1 $(A)$ and GLYT2 $(B)$ in the ventral horn of the spinal cord. $A$, Immunoreactive glial processes are detected surrounding terminals ( $T$ ) (arrowhead), dendrites $(D)$ (long arrows), and blood vessels (thick arrows). $B$, GLYT2 immunoprecipitate (arrows) inside a terminal bouton $(T)$ apposed to a dendrite $(D)$ ). Since immunoreagents must diffuse to the cytoplasmic space, not all structures of a kind are necessarily labeled. Scale bar, $500 \mathrm{~nm}$.

tibodies specifically recognizing GLYT1 and GLYT2, respectively (Fig. 1). The production and characterization of the anti-GLYT1, anti-GLYT2 antibodies (termed anti-GLYT1-f and anti-GLYT2-f) as well as the epitope mapping of anti-GLYT1-f antibodies have been described in detail elsewhere (Olivares et al., 1994; Zafra, Gomeza, Olivares, Aragón, and Giménez, unpublished observations). However, in those studies the antibodies were used as crude sera. In the present report we performed an affinity purification of the antibodies. Moreover, a new antibody was raised against a peptide consisting of amino acids residues 623-638 of the GLYT1 sequence (termed anti-GLYT1p). After purification, the antibody anti-GLYT1-f (lanes 2-14) kept the same characteristics as the crude serum (lane 1) (Fig. $2 A$ ). Anti-GLYT1-f recognized a single but broad band between 50 and $70 \mathrm{kDa}$. The intensity of the bands was quantified by densitometric analysis. In agreement with our previous results, the protein was abundantly expressed in the spinal cord $(100 \%)$, the brainstem $(214 \%)$ and the cerebellum $(152 \%)$, and rather low levels were found in the hippocampus $(15 \%)$ and the cortex $(16 \%)$. These results have now been expanded to other brain regions and to non-nervous tissue. High expression of the protein was observed in the thalamus/hypothalamus $(116 \%)$ and moderate in the striatum $(52 \%)$ and retina $(56 \%)$. In the olfactory bulb, the expression was rather low ( $20 \%)$ and the protein was of a smaller size than in the rest of the brain. By contrast, the size of the protein in the retina was slightly higher. These differences in size could be due either to regional differences in the degree of glycosylation or to differential expression of GLYT1 isoforms. The protein was not detected in peripheral tissue such as lung, liver, spleen, uterus, or kidney. Similar results were obtained with the anti-GLYT1-p antibody (Fig. 2B), except for the presence of an unidentified band of $95 \mathrm{kDa}$ in some peripheral tissues. The protein detected by the affinity purified anti-GLYT2-f (Fig. 2C) appeared as a broad band between 

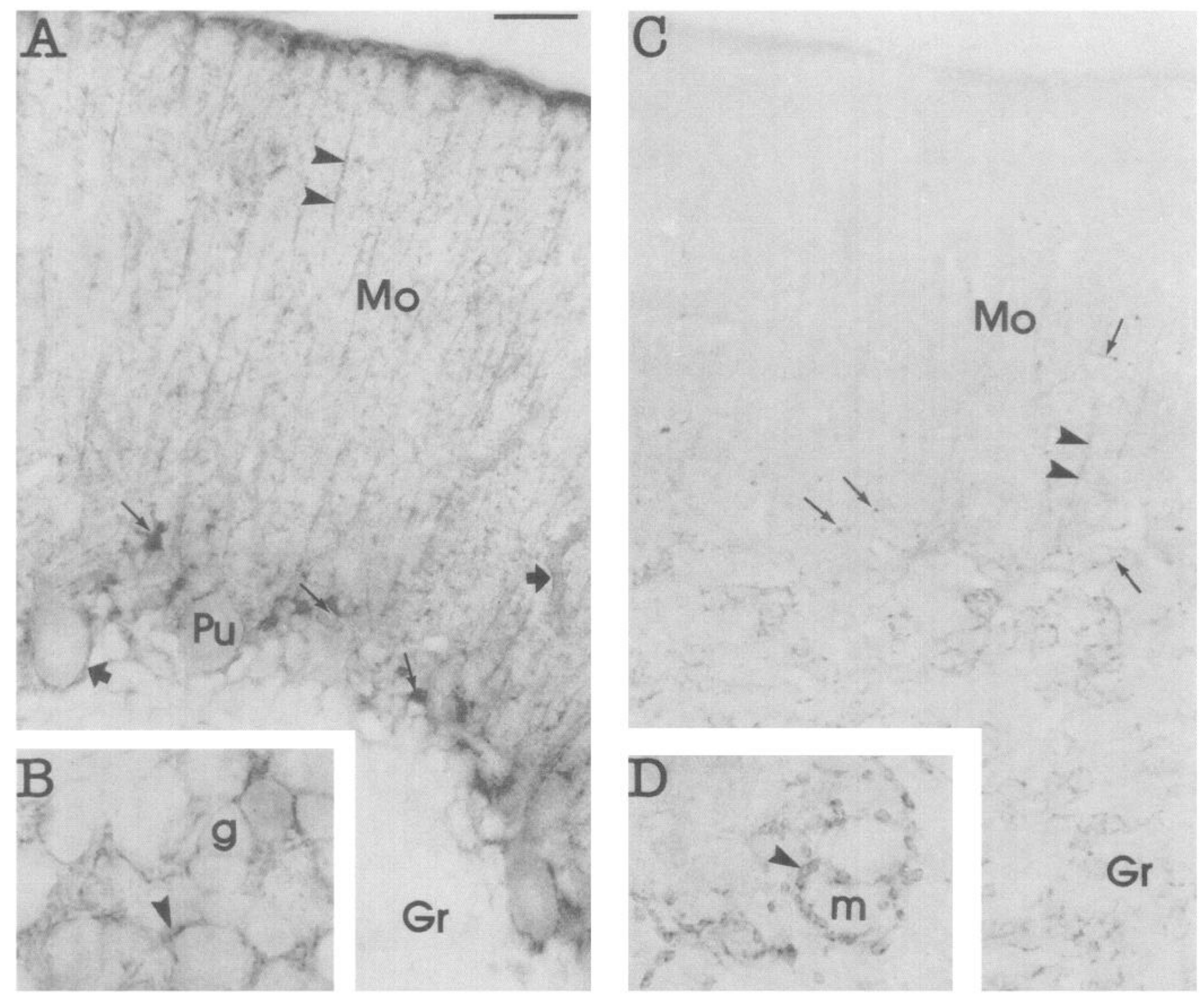

Figure 6. Localization of GLYT1 and GLYT2 in the cerebellum. A, GLYT1 staining in cell bodies (arrows) and radial fibers (arrowheads) of Bergmann glia in the molecular layer $(\mathrm{Mo})$. Purkinje cell bodies $(\mathrm{Pu})$ and dendrites are surrounded by glial elements (short arrows). A weak cytoplasmic staining is observed in Purkinje cell bodies and dendrites. B. Higher magnification of granular layer $(G r)$ after GLYT1 staining. It is possible to distinguish processes (arrowheads) around glomeruli and around granular cells $(\mathrm{g})$. C. GLYT2 stained axon terminals (arrows) and weakly stained glial fibers (arrowheads) in the molecular layer $(M o)$; stained axons and terminals in the granular layer (Gr). D, GLYT2 in glomeruli in the granular layer. Note numerous labeled Golgi cell terminals (arrowhead) around unlabeled mossy fiber terminals $(m)$. Scale bar: $25 \mu \mathrm{m}$ for $A$ and $C, 10 \mu \mathrm{m}$ for $B$ and $D$.

75 and $100 \mathrm{kDa}$ and was expressed at high levels in caudal parts of the brain: spinal cord $(100 \%)$ and brainstem (148\%), at moderate levels in the cerebellum $(40 \%)$, and at low levels in the thalamus/hypothalamus $(10 \%)$. No expression of GLYT2 was observed in other brain regions nor in peripheral tissues.

\section{Immunocytochemical localization}

Regional distribution. The regional distributions of staining intensities for GLYT1 and GLYT2 were examined in material treated to have an optimal penetration of the antibodies, i.e., fixation in a medium with low glutaraldehyde, but containing picric acid, and inclusion of Triton X-100 with the antibodies. The differences in the regional distribution of GLYT1 and GLYT2 revealed by immunocytochemistry (Fig. 3) were in agreement with those determined by immunochemical analysis
(Fig. 2). Figure 3 presents a low magnification survey by parasagittal sections of the rat brain, whereas Table 1 gives a detailed anatomical description obtained by microscopic inspection of consecutive coronal sections. For both proteins, the highest levels of expression were found in caudal parts of the brain, that is, pons/medulla, cerebellum, and spinal cord (compare Fig. 4). For GLYT1, additional immunoreactivity was detected in other regions. Relatively high concentrations of this protein were observed in some areas of the mesencephalon and basal forebrain (such as the bed nucleus of the stria terminalis, supraoptic nucleus, ventral hypothalamus, zona incerta, substantia nigra, and the colliculi), whereas in regions of the cerebral hemispheres such as neocortex, hippocampus, or basal ganglia, the immunoreactivity was weak.

Cellular and ultrastructural localization. Immunoreactivity in 

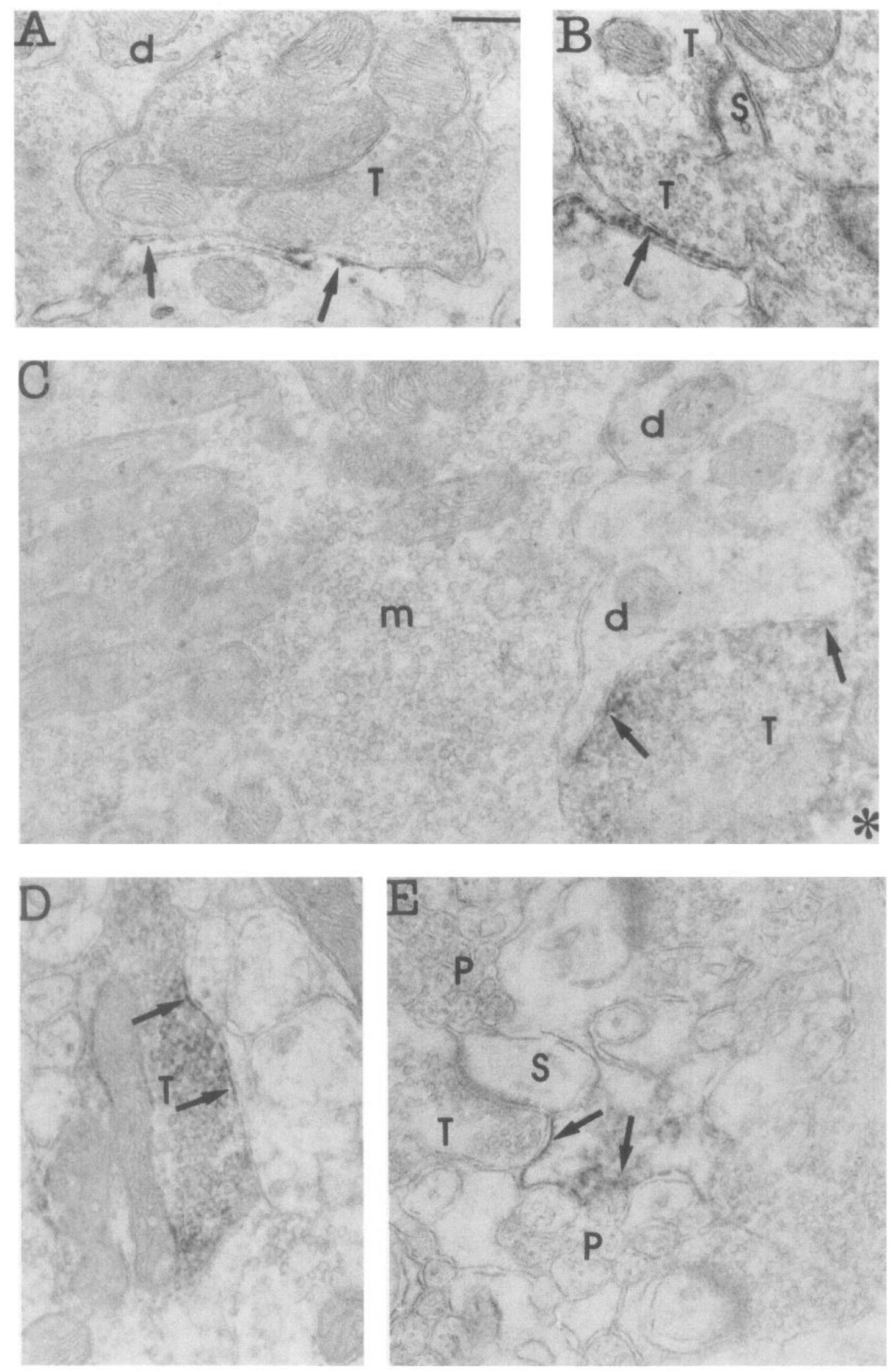

Figure 7. Electron micrographs of distribution of immunoreactivity for GLYT1 $(A$ and $B)$ and GLYT2 $(C, D$, and $E)$ in the cerebellum. $A$, Immunoreactive glial process (arrows) surrounding a nerve terminal $(T)$ with pleomorphic vesicles (possibly from a Golgi cell) in the granular layer. $B$, GLYTI immunoreactive glial process (arrows) surrounding an unlabeled terminal $(T)$ in the molecular layer. $C$, GLYT2 immunoprecipitate in a Golgi cell axon terminal $(T)$ apposed (arrows) to an unlabeled granular cell dendrite $(d)$ next to a mossy fiber terminal $(m)$. The terminal has 
the different regions of the brain was analyzed at higher resolution by light microscopy and pre-embedding electron microscopy. To obtain optimal resolution of structural details, Triton $\mathrm{X}-100$ was omitted. This resulted in a reduced staining intensity, which was compensated for by increasing the antibody concentration. A very different cellular staining pattern was obtained for the two proteins. GLYTI stained mainly astrocyte-like perikarya and processes both in gray and white matter. Weak staining of neuronal cytoplasm was also observed for this protein. A very similar staining pattern was obtained with the antiGLYT1-p as with the anti-GLYT1-f antibodies. Only results with the latter antibody will be shown in the subsequent comparative analysis. By contrast, GLYT2 antibodies stained almost exclusively axons and especially terminal boutons. Light microscopically these appeared as stained tubes or rings (e.g., Fig. $4 D$ ). Electron microscopically, the reaction product was most concentrated along the periphery of the structures, whether stained for GLYT1 or GLYT2, spreading toward the interior but not into the extracellular space (e.g., Fig. 5). The specific features of immunoreactivity in selected regions of the rat CNS are described separately in the following paragraphs.

Spinal cord. Both proteins were abundantly expressed in the gray matter of the spinal cord. However, important differences in the localization of the transporters could be appreciated even at low magnification (Fig. $4 A, B$ ). The expression of GLYT1 was very high in the layers I and II, an area where the expression of GLYT2 was only moderate. In turn, GLYT2 was highly expressed in lamina III. However, whereas numerous GLYT2-positive structures were observed in the lateral and ventral funiculi (Fig. 4B), no evidence for specific axonal GLYT1 staining was obtained. The delicate processes of glial cells penetrated in between the perikarya of the neurons forming a dense network around dendrites and perikarya. The network was especially dense around motoneurons (recognized by their large size) (Fig. $4 C$ ), which are known to have glycinergic inputs, and in the dorsal horn (Fig. $4 E$ ), that also expresses high levels of strychnine-sensitive glycine receptors. In the white matter, numerous labeled glial cells were observed (Fig. 4G). In contrast, a high density of GLYT2 immunoreactivity was found in ring-shaped boutons-like structures located around neurons, conspicuously around motoneurons but also in the neuropil (Fig. 4D). Stained boutons in the dorsal horn of the spinal cord were much smaller than those in the ventral horn (Fig. $4 F$ ). Abundant labeled axons were also observed in the white matter, particularly close to the gray matter, the zone abundant in propriospinal axons (Fig. $4 B, H)$.

In the ventral horn of the spinal cord, the patterns observed for these two proteins at the light microscope level were confirmed by pre-embedding electron microscopy (Fig. 5). GLYT1 positive astrocytic process occurred close to synaptic terminals and perivascularly (Fig. 5A). GLYT2 was located in bouton apposed to dendrites (Fig. 5B) and cell bodies (not shown).

Cerebellum. GLYT1 and GLYT2 are expressed in the cerebellum but with differential patterns (Fig. 6). GLYT1 was found in very high amounts in the molecular layer, mainly localized in the cell bodies and fibers of the Bergmann glia, the latter ("Golgi epithelial cells") being packed in between the Purkinje cell bodies (Fig. 6A). Glial staining was also observed around granular cells (Fig. $6 B$ ). Moreover, a weak staining in Purkinje cell bodies and dendrites was observed.

GLYT2 was found mainly in tiny rings outlining the glomeruli of the granular cell layer (Fig. 6C,D). The centers of the glomeruli were not staincd, indicating that the immunoreactivity was not in the mossy fiber terminals but rather in the terminals of the Golgi cells (Fig. 6D). A small number of stained axons were observed in the molecular layer (Fig. $6 C$ ). In contrast with the observations made in other parts of the brain, GLYT2 immunoreactivity also occurred in glial elements in the molecular layer (Fig. 6C). Both proteins were also present in the cerebellar nuclei, where the cell staining pattern was similar to that in the rest of the brain, that is, glial for GLYT1 and neuronal for GLYT2. These localizations for GLYT1 and GLYT2 were confirmed at the ultrastructural level (Fig. 7), the structures being identified according to Palay and Chan-Palay (1974). GLYT1positive glial processes occur adjacent to nerve terminals both in the granular cell layer (Fig. 7A) and in the molecular layer (Fig. 7B). In the former layer, GLYT2-positive Golgi cell terminals were seen contacting dendritic digits next to mossy fiber terminals (Fig. 7C). GLYT2-labeled terminals (Fig. 7D) as well as glial profiles (Fig. $7 E$ ) were observed in the molecular layer of the cerebellum.

Brainstern auditory system. Several nuclei of this system were among the most intensely labeled areas of the brain for both glycine transporters (Table 1). Dorsal and ventral cochlear nuclei were strongly positive for both GLYT1 and GLYT2, although important differences in distribution were observed. In the dorsal cochlear nucleus, a gradient of immunoreactivity for both proteins could be observed from the outer (highest activity) to the inner layers (Fig. 8A,B). This was more apparent for GLYT1. In the ventral cochlear nucleus, the superficial granule cell layer was more evenly labeled for both proteins than the central magnocellular part. The difference could in part be explained by the presence of more myelinated fibers in the latter. The octopus cell area was distinctly less labeled for GLYT2 than the rest of the nuclear complex, while no such difference was found for GLYT1. This observation fits well with the scarcity of glycinepositive afferents to the octopus cells (Wickesberg et al., 1991; Kolston et al., 1994). Like in the spinal cord and other areas described below, GLYT1 was concentrated in a network of delicate astrocytic processes that run through the neuropil and ensheathe the cell bodies and terminal boutons (Fig. 8C). GLYT2 immunoreactivity was concentrated in boutons both in the neuropil and around the cell bodies (Fig. 8D).

In the superior olivary complex, GLYT1 immunoreactivity was high in the lateral superior olive (LSO), medial nucleus of the trapezoid body (MNTB), and part of the periolivary region, while it was moderate in the superior paraolivary nucleus (SPN) and the medial superior olive (MSO) (Fig. 9A). A pattern of glial cell staining similar to that observed in other areas was obtained (Fig. 9C,E). The trapezoid body showed the highest

$\leftarrow$

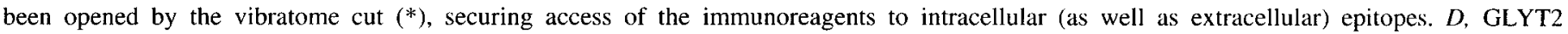

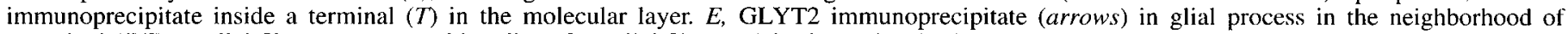

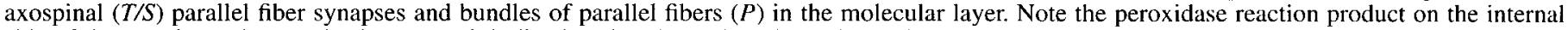

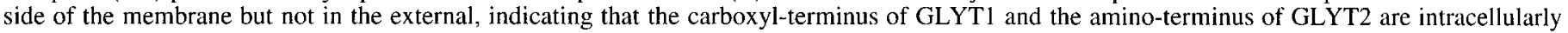
located. Scale bar, $250 \mathrm{~nm}$ for $A-E$. 

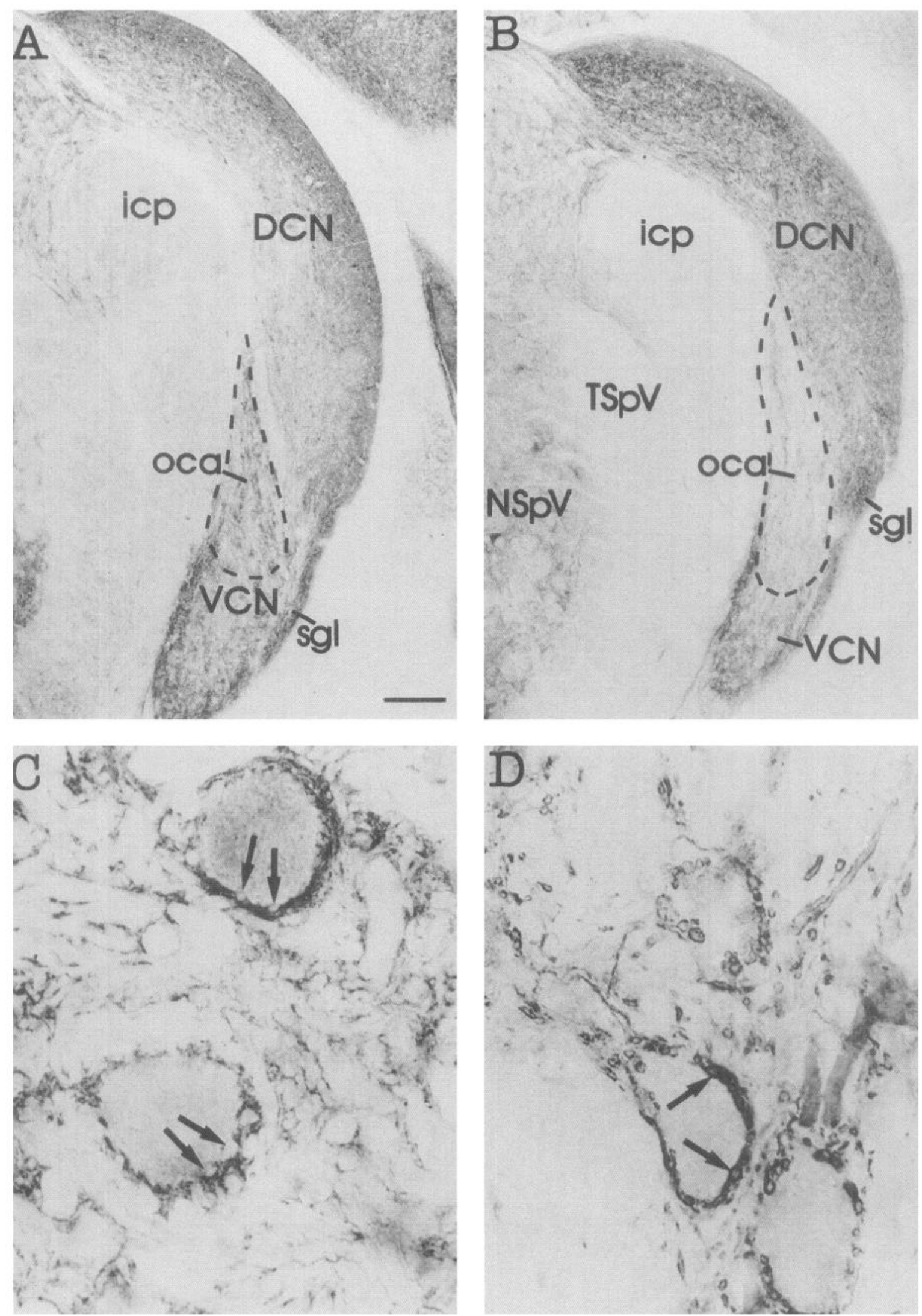

Figure 8. Localization of GLYT1 $(A$ and $C$ ) and GLYT2 $(B$ and $D)$ in the cochlear nuclei. $A$ and $B$, Low magnification of the dorsal cochlear nucleus $(D C N)$ and ventral cochlear nucleus $(V C N)$. Note that the octopus cell area (oca, circumscribed by stippling) is low in GLYT2. $C$, High magnification of neurons in the VCN. Note dense GLYT1 immunoreactive glial network around cell bodies and around putative immunonegative terminal boutons (arrows). D, High magnification of neurons in the VCN. Note GLYT2 immunoreactive boutons (arrows) concentrated around neurons. $C$ and $D$ are from areas other than the oca. Other abbreviations: icp, inferior cerebellar peduncle; $N S p V$, nucleus of the spinal tract of the trigeminal nerve; $s g l$, superficial granular layer; $T S p V$, spinal tract of the trigeminal nerve. Scale bar: $250 \mu \mathrm{m}$ for $A$ and $B$, $10 \mu \mathrm{m}$ for $C$ and $D$. 

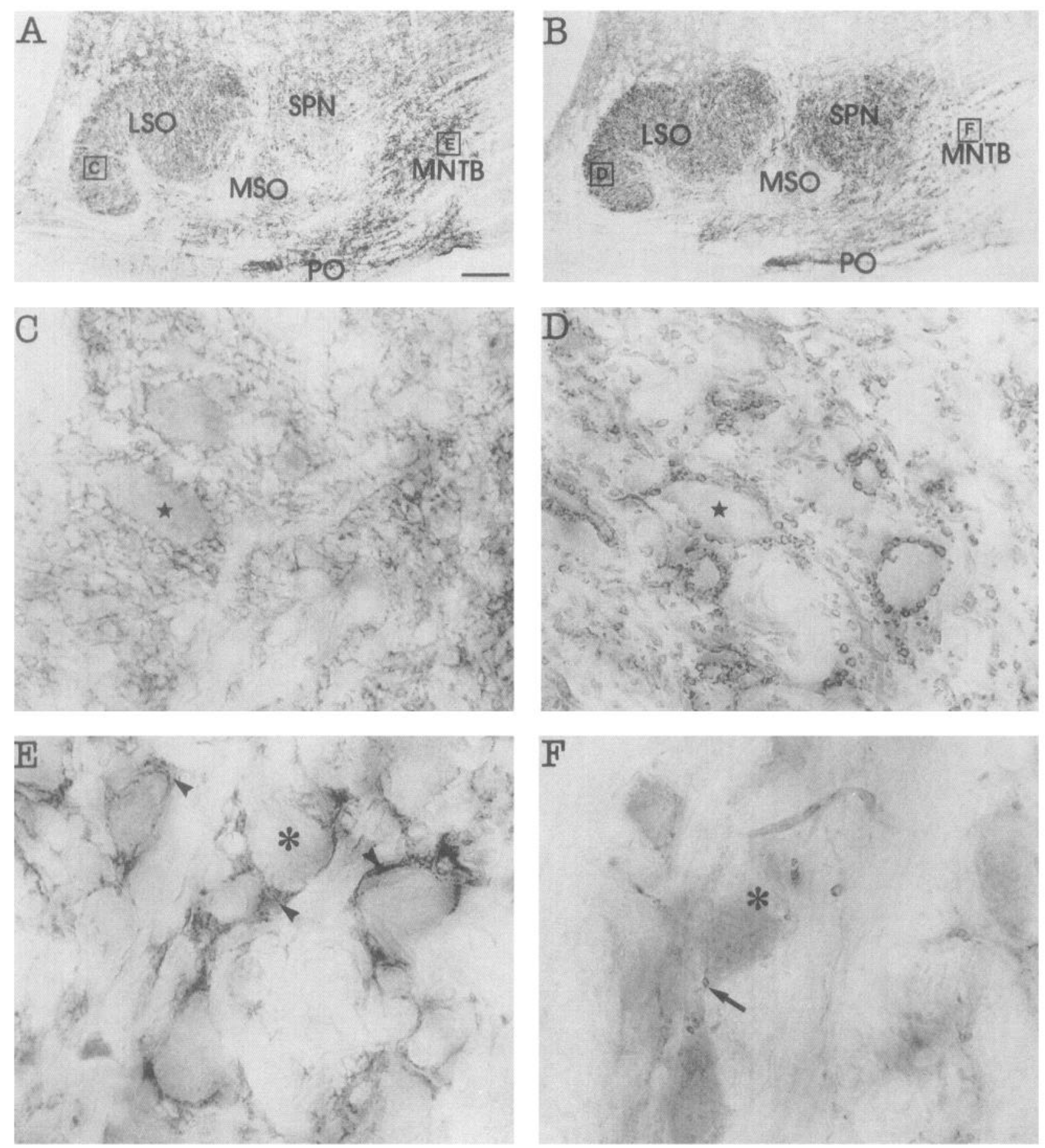

Figure 9. Localization of GLYT1 $(A, C$, and $E)$ and $\operatorname{GLYT} 2(B, D$, and $F)$ in the superior olivary complex. Boxed areas from the low magnification for GLYT1 $(A)$ or GLYT2 $(B)$ are magnified where indicated. $C$, Neurons $($ star $)$ and putative terminals of the lateral superior olive are surrounded by GLYT1 immunoreactive glial elements. $D$, GLYT2 immunoreactive terminals located both in the neuropil and around neurons (star) of the lateral superior olive. E. Dense network of GLYT1 immunostained glial processes (arrowheads) surrounding neuronal cell bodies (*) and processes in the medial nucleus of the trapezoid body. F, Cytoplasmic GLYT2 staining in neurons of the medial nucleus of the trapezoid body (*). These neurons receive very sparse GLYT2-positive boutons (arrow) but project glycinergic terminal inter alia onto the above-described neurons of the lateral superior olive. Abbreviations: $L S O$, lateral superior olive; $M N T B$, medial nucleus of the trapezoid body; $M S O$, medial superior olive; $P O$, periolivary region; $S P N$, superior paraolivary nucleus. Scale bar: $220 \mu \mathrm{m}$ for $A$ and $B, 10 \mu \mathrm{m}$ for $C-E$.

density of staining for GLYT1 of all the structures analyzed in the brain, the immunoreactivity being concentrated in the glial elements around the cell bodies (Fig. 9E). A weak cytoplasmic GLYT1 labeling of neuronal cell bodies was also observed in this nucleus. GLYT2 immunoreactivity was high in the LSO,
SPN, and the periolivary region but was low in MNTB (Fig. $9 B$ ). The pattern of stained tubes (axons) and tiny rings (boutons) was similar to that in other regions. In the LSO and SPN, the boutons were densely studded around the cell bodies, defining perfectly the contours of the immunonegative neurons (Fig. 
9D). By contrast, in the MNTB the immunorcactivity for GLYT2 was concentrated in the cell bodies of the neurons and in their axons, but only occasionally stained terminals were observed (Fig. 9F).

The staining in the dorsal and ventral lateral lemniscus was moderate to high for both proteins, while in the medial lemniscus GLYT2 immunoreactivity was weaker than in the above described auditory muclei (Table 1), but it was concentrated in the perikarya of some neurons that appeared completely surrounded by synaptic terminals. A very weak immunoreactivity was observed in the neuropil of this nucleus.

The inferior colliculus had a high GLYT1 immunoreactivity in the dorsal cortex (except in layer 1) and moderate in the central nucleus. The density of GLYT2-positive terminals in this nucleus was moderate, although it was relatively high in the ventral part of the central nucleus, which has been described to be rich in glycine immunoreactive terminals.

Other brainstem sensory systems. GLYT1 was very abundant in somatosensory nuclei such as the cuneate, gracile, and spinal trigeminal (Table 1). The cellular pattern was glial, very similar to that observed in spinal cord and other areas of the brainstem. The immunoreactivity for GLYT2 was high in the spinal trigeminal nucleus and moderate in the cuneate and gracile. In these nuclei, it was concentrated in boutons of smaller size than in other brainstem nuclei. Whereas in the cuneate and gracile, the staining was higher around the cells, in the spinal trigeminal the labeling was much stronger in the neuropil.

In the solitary tract nucleus, a high GLYT1 immunoreactivity (Table 1) was observed, again concentrated in astrocytic processes. However, GLYT2 immunoreactivity was completely absent in the medial part of this nucleus, although a moderate to low number of terminals were labeled in the lateral part.

Strong glial GLYT1 staining occurred in the vestibular system (Table 1). GLYT2 immunoreactivity was rather high in the different vestibular nuclei, with labeled boutons evenly distributed among the cell bodies and the neuropil.

The distribution of GLYT1 immunoreactivity in the superior colliculus was quite similar to that observed in the inferior colliculus, with strong staining in the outer layers, zonal, and superficial gray, and moderate in morc internal layers (Fig. 3). GLYT1 was also relatively high in the optic tract nucleus and posterior pretectal nucleus and low in the anterior pretectal nucleus. The staining was over glial cells, with a pattern similar to that observed in the rest of the brainstem. GLYT2 immunoreactivity in these nuclei of the visual system was sparse but somehow followed a pattern complementary to that of GLYT1. Whereas GLYT2 was undetectable in outer layers of the superior colliculus and in the optic and posterior pretectal nuclei, some dispersed terminals were found in internal layers of the superior colliculus and in the anterior pretectal nucleus.

Brainstem motor nuclei. A high level of GLYT1 immunoreactivity was observed in various cranial motor nuclei such as the oculomotor, the trigeminal motor, abducent, hypoglossal (Table 1), and, specially, in the facial nucleus (Fig. 3). Like in the spinal cord, GLYT1 immunoreactivity was located in the delicate processes of the astroglial cells. GLYT2 immunoreactivity was also high in these nuclei, except in the oculomotor. Microscopic examination revealed abundant, large GLYT2-positive boutons both in the neuropil and apposed to the perikarya of motoneurons, although the density was not high enough to form rings around the neurons, as happened in the auditory system. In the trigeminal nucleus, the density of boutons around the motoneurons was slightly higher than in the other cranial motor nuclei.

Brainstem reticular formation. Glial GI,YT1 immunoreactivity was high and evenly distributed over nuclei of the reticular formation, whereas GLYT2 showed a rostrocaudal gradient (Fig. 3 ), from moderate levels in the pontine reticular nucleus (oralis and caudalis), to high in the parvocellular reticular nucleus, gigantocellular reticular nucleus, medullary reticular formation, and lateral reticular nucleus.

Other brainstem areas. The substantia nigra showed moderate to high glial staining for GLYTl both in the compact and in the reticular parts, whereas a very weak immunoreactivity for GLYT2 was observed in isolated bouton- and axon-like structures of both parts, being slightly stronger in the compact part. The neurons of the locus ceruleus were surrounded by a dense network of GLYTI positive glial processes, whereas the number of GLYT2 positive boutons was moderate. In the pontine nuclei, tegmental nuclei, and inferior olive, the glial GLYT1 labeling was strong, whereas GLYT2 was almost undetectable. In the central gray, there were also a high staining intensity for GLYT1 and a weak for GLYT2. Strong labeling was observed for GLYT1 and GLYT2 in the dorsal parabrachial area (see Table 1, Fig. 3).

Diencephalon. Several nuclei of the thalamus showed moderate immunoreactivity to GLYTI antibodies. The highest levels were found in the zona incerta, reticular nucleus (Fig. 3), ventroposterior thalamic nucleus parvocellular, laterodorsal nucleus, and anteroposterior nucleus (Table 1). This immunoreactivity was located in the glial cells, like in more caudal regions. In the rest of the thalamic nuclei, the staining was low and the reaction product was located in some isolated astrocytes that formed a diffuse network around neurons and capillaries. Weak immunoreactivity was also observed in the cytoplasm of most of the neurons of the thalamus. For GLYT2, the immunoreactivity was very weak or not detectable. Only some sparse terminals were observed in the zona incerta.

In most of the nuclei of the hypothalamus the staining for GLYT1 was higher than in the thalamus. The staining pattern was again glial for GLYT1. In the supraoptic hypothalamic nucleus and in other ventral nuclei the staining was higher than in the rest of the hypothalamus. No GLYT2 positive structures were found.

Cerebral hemispheres. In these areas of the brain only GLYT1 immunoreactivity was present and the staining pattern was similar in all of them. The highest concentration was found in astrocytes in layer I of the cortex (Fig. 10A,C) as well as dispersed in the different layers of the hippocampus (Fig. 10B), in the striatum, the septum, and the amygdala. Some perivascular end feet were also observed. However, the dense network of glial elements observed in the brainstem and spinal cord was not so well defined in these forebrain areas and only a faint staining in astrocytic processes around neuronal cell bodies was detected. Moreover, a weak immunoreactivity was detected in most of the neurons of these areas, being more conspicuous in layer $\mathrm{V}$ of the cortex (Fig. 10A), the piriform cortex, the pyramidal, and granular cell layers in the hippocampus (Fig. 10B,D) and in the amygdala.

Olfactory bulb. GLYT1 but not GLYT2 was detected in the olfactory bulb. High levels were observed in glial cells in the periglomerular areas, although isolated astrocytes were observed in other part of the bulb as well (Fig. 11). A diffuse cytoplasmic 

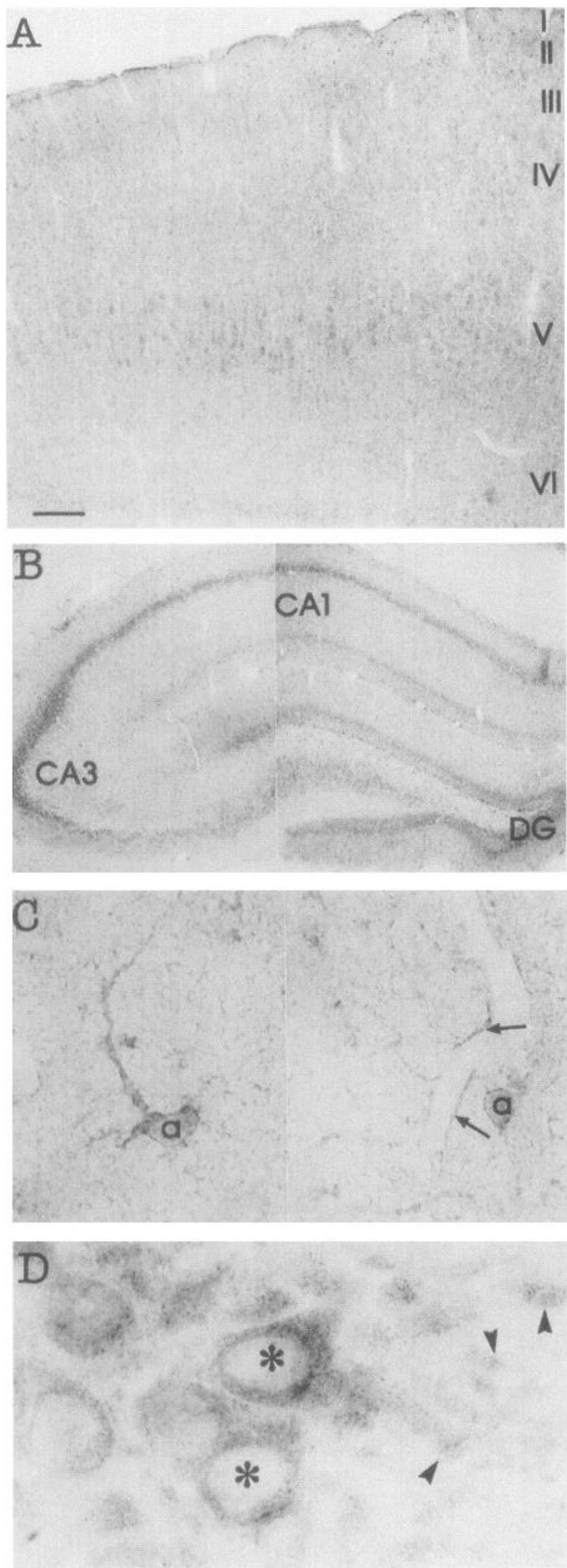

Figure 10. Localization of GLYT1 in the cerebral neocortex ( $A$ and $C$ ) and hippocampus $(B$ and $D)$. $A$, Reaction product is observed in astrocytes in layer $\mathrm{I}$ as well as in neuronal cell bodies, especially in layer V. $B$, Hippocampus shows immunoreactivity in disperse astrocytes and in neurons of the pyramidal cell layer (CA1, CA3 areas) and granular cells in the dentate gyrus $(D G) . C$, High magnification of astrocytes (a) from layer I of the cortex. Note the immunoreactive perivascular end feet (arrows). D. High magnification of pyramidal neurons of the

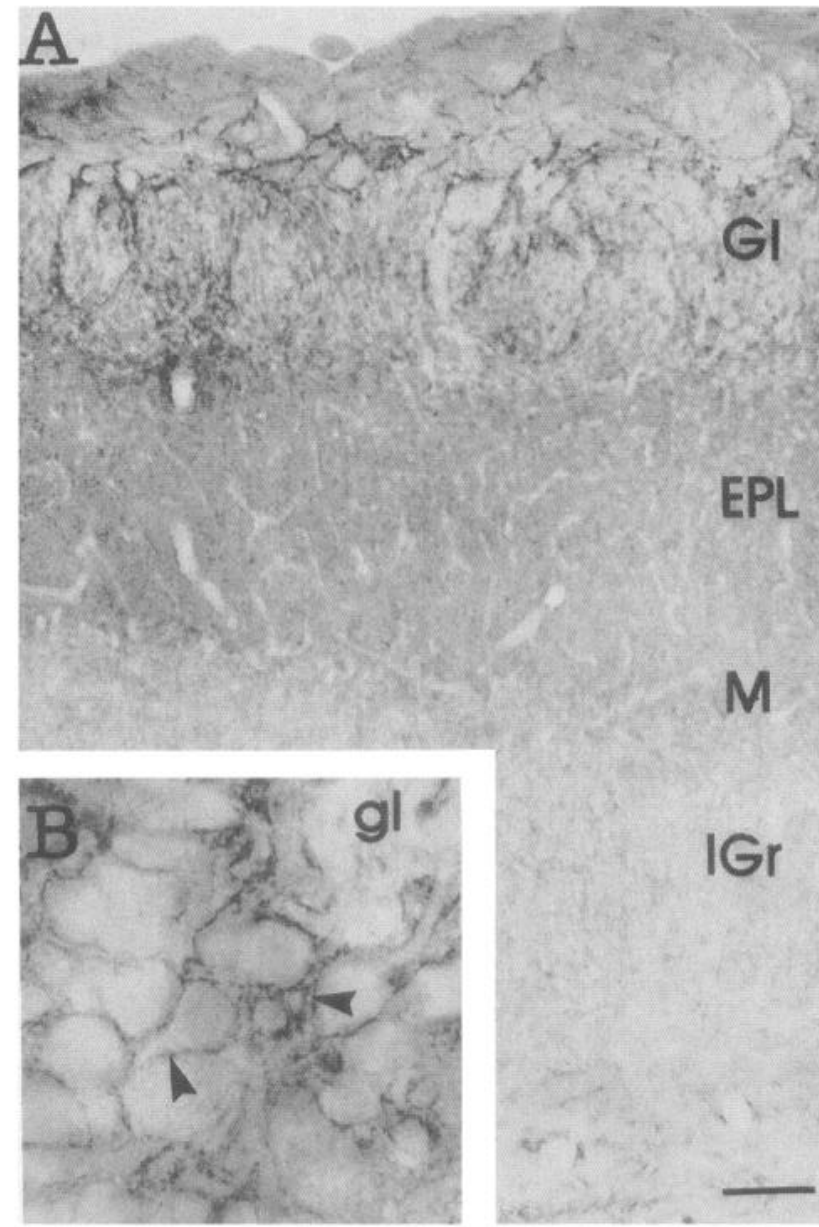

Figure 11. Localization of GLYT1 in the olfactory bulb. A, Immunoreactivity is concentrated in the glomerular layer. $B$, Higher magnification of periglomerular area. Immunoreactive glial elements (arrowheads) are very abundant around periglomerular cell bodies and processes and sparser in the glomeruli $(g l)$. Abbreviations: $G l$, glomerular layer; $g l$, glomeruli, $E P L$, external plexiform layer; $M$, mitral cell layer; $I G r$, internal granular layer. Scale bar: $100 \mu \mathrm{m}$ for $A, 10 \mu \mathrm{m}$ for $B$.

staining, similar to that observed in other areas of the forebrain, was apparent in neurons of the mitral and granular cell layers.

Retina. In the retina GLYT1 but not GLYT2 was observed (Fig. 12). As elsewhere, the pattern was similar with the antifusion protein antibody and with the anti-peptide antibody. In contrast to the rest of the CNS, the GLYT1 pattern was not glial but immunoreactivity was located in neurons of the inner nuclear layer (INL) and in boutons of the inner plexiform layer (IPL). The stained neurons were concentrated in the internal part of the INL. Both localization and morphology indicate that these cells were amacrine neurons.

\section{Discussion}

The present article describes the localization in the CNS of two glycine transporter proteins (GLYT1 and GLYT2) by immunochemistry (Western blot) and immunocytochemistry (pre-em-

$\leftarrow$

CA3 region. Note the cytoplasmic granular staining both in cell bodies $\left.{ }^{*}\right)$ and in transversally cut dendrites (arrowheads). Scale bar: $200 \mu \mathrm{m}$ for $A, 300 \mu \mathrm{m}$ for $B, 8 \mu \mathrm{m}$ for $C, 10 \mu \mathrm{m}$ for $D$. 


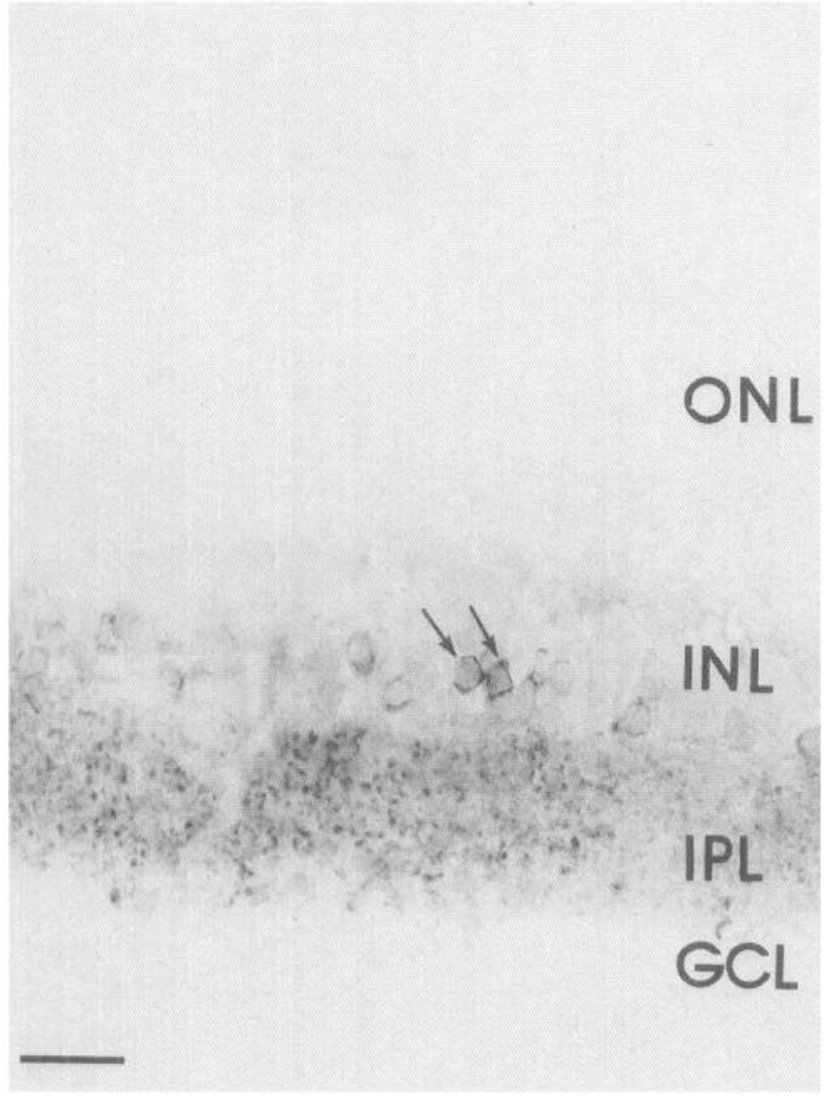

Figure 12. Localization of GLYT1 in retina. Staining is observed in amacrine cell bodies (arrows) and in terminals in the inner plexiform layer $(I P L)$. Other abbreviations: $O N L$, outer nuclear layer; $I N L$, inner nuclear layer; $G C L$, ganglion cell layer. Scale bar, $25 \mu \mathrm{m}$.

bedding light and electron microscopy). The expression of these proteins was studied with antibodies against specific sequences of each transporter. The purified antibodies used were shown by Western blotting and absorption with antigen to be specific for GLYT1 and GLYT2, respectively. Our results demonstrate a clear differential expression of the two transporters, both at the regional and at the cellular level. Quantitative immunochemical methods show that both proteins are abundantly expressed in caudal regions of the CNS spinal cord, brainstem, and cerebellum, while GLYT1, but not GLYT2, is detected in more rostral regions of the brain. The expression in these rostral areas ranges from relatively high GLYT1 values in the hypothalamus and thalamus to rather low values in the cerebral hemispheres. These results suggest an association of both proteins with inhibitory glycinergic neurotransmission in caudal regions of the CNS and additional functions for GLYT1 both in caudal and in forebrain regions devoid of strychnine-sensitive glycine receptors.

\section{Glycine transporters in glycinergic neurotransmission}

The relationship of these proteins to glycinergic neurotransmission is emphasized by immunocytochemical data that show high levels of GLYT2 protein in presynaptic elements of synapses thought to be glycinergic. Moreover, these synapses are surrounded by glial cells expressing high levels of GLYT1. The presence of GLYT1 in glial plasma membranes surrounding synapses reinforce a role of glia in the modulation of the extracellular concentrations of neuroactive substances. In fact, the pres- ence of a high-affinity glycine transport in glial cells has been shown in several experimental systems (Zafra and Giménez, 1986, 1989; Holopanien and Kontro, 1989; Fedele and Foster, 1992). In spite of the presence of glycine transporter in glial cells, the cytoplasmic concentration of glycine, as determined by immunocytochemistry, is rather low in astrocytes (Ottersen et al., 1990). However, glycine entering the glial cells could be quickly metabolized by the glycine cleavage system, an enzymatic complex that has been found to be enriched in astrocytes (Sato et al., 1991).

The expression of GLYT2 is in general in good agreement with the distribution of glycine receptors, as reported by immunocytochemistry (Araki et al., 1988; van den Pol and Gores, 1988; Wenthold et al., 1988) and strychnine binding studies (Zarbin et al., 1981) and with that of glycine immunoreactivity (Ottersen et al., 1987, 1988; Wenthold et al., 1987; van den Pol and Gores et al., 1988; Kolston et al., 1992). Thus, the highest levels of GLYT2 are found in the dorsal and ventral horn of the spinal cord, in the auditory system and in the nuclei of the cranial nerves. All these areas are known to express high levels of the strychnine-sensitive glycine receptor. The reverse is also true: areas without glycine receptor are also low in GLYT2. For instance, neither receptor nor GLYT2 are found in the cerebral hemispheres or in nuclei such as the superior colliculi, the solitary tract nucleus, or the inferior olive among others. One notable exception is the retina that expresses glycine receptors but not GLYT2 (see below). The relationship between GLYT2 and inhibitory glycinergic neurons becomes clear if the data obtained from regions especially well characterized for glycinergic neurotransmission are analyzed in detail. One of these areas is the superior olivary complex (Helfert et al., 1989), which functions to determine the location of sounds (Jenkins and Masterson, 1982; Sanes 1990). Neurons in the LSO are excited by ipsilateral sounds and inhibited by the simultaneous presentation of similar contralateral sounds. Ipsilateral input to LSO is excitatory and derives from the ipsilateral VCN (Warr, 1966). In turn, contralateral input derives from the contralateral $\mathrm{VCN}$ and reaches the LSO indirectly. The MNTB is interposed between the contralateral VCN and the LSO. The projection from the MNTB to the ipsilateral LSO (Spirou et al., 1990) is inhibitory and uses glycine as neurotransmitter. Numerous studies have demonstrated both $\alpha$-subunit receptor immunoreactivity (Aoki et al., 1988) and high binding of ${ }^{3} \mathrm{H}$-strychnine in the LSO (Sanes et al., 1987; Glendennig and Baker, 1988). Electrophysiological data have shown the presence of strychnine-sensitive synapses in the LSO (Moore and Caspary, 1983; Wu and Kelly, 1991). Other studies have shown a high-affinity uptake of ${ }^{3} \mathrm{H}$-glycine in terminals in the LSO (Schwartz, 1985). Furthermore, the MNTB cells, their axons, and their axon terminals in the LSO are glycine immunoreactive (Wenthold et al., 1987; Aoki et al., 1988). The GLYT2 immunoreactivity of the MNTB cell bodies obtained in the present report probably represents biosynthesis of the protein (see below on GLYT2 mRNA). Then, the protein would be sorted by axonal transport to the terminals surrounding the neurons of the LSO, where it reaches a very high concentration. Thus, the observed high level of glycine in the cytoplasm and terminal boutons of these neurons could be a consequence of the concentrative task performed by GLYT2. This motif repeats itself in other brain areas. For instance, in the cerebellum, where Golgi cells are known to accumulate ${ }^{3} \mathrm{H}$-glycine (Wilkin et al., 1981; Ottersen et al., 1987) and to express GLYT2 mRNA (Zafra, Gomeza, Olivares, Aragón, and Giménez, unpublished 
observations). The terminals of these cells in the glomeruli con tain high levels of GLYT2 immunoreactivity (present report) and, again, both Golgi cell bodies and terminals contain high glycine concentrations (Ottersen et al., 1987, 1988). However, in the granular layer of the cerebellum the strychnine-sensitive glycine receptor has not been found. Nevertheless, granular cells express mRNA $\alpha 3$ and $\beta$ subunits of the glycine receptor (Malusio et al., 1991).

The retina constitutes a notable exception with respect to the roles performed by GLYT1 and GI,YT2. In this region, only GLYT1 has been detected both by immunochemistry and by immunocytochemistry. In contrast to the situation in the rest of the CNS, GLYT1 is not located in glial elements, but is found on the amacrine neurons of the inner part of the inner nuclear layer (INL) and in terminals of the inner plexiform layer (IPL). Strychnine-sensitive glycine receptor are present in the IPL, in neuronal elements postsynaptic to glycine-immunoreactive amacrine cell processes (Pourcho and Goebel, 1987; Davanger at al., 1991; Crooks and Kolb, 1992; Grüner and Wassle, 1993). Moreover, $\mathrm{H}$-glycine uptake has been shown in amacrine cells by autoradiographic studies (Bruun and Ehinger, 1974; Pourcho and Goebel, 1985). Also, NMDA receptors have been described on ganglion cells in retina (Massey and Miller, 1990).

\section{Localization of GLYT2 correlates with GLYT2 mRNA}

For GLYT2, a very good agreement between immunocytochemical data and mRNA distribution, as revealed by in situ hybridization (Zafra, Gomeza, Olivares, Aragón, and Giménez, unpublished observations), was found. Thus, GLYT2 protein has been found in two types of areas; first, those places where the GLYT2 mRNA is also present, and second, in areas devoid of GLYT2 mRNA but known to have afferents from the place where the mRNA has been localized. Examples of the first type of places are the spinal cord or the medullary reticular formation, where the probable source of glycinergic terminals are local interneurons. An example of the second type of areas is the inferior colliculus where the mRNA has not been detected but which receives glycinergic inputs from the $\mathrm{LSO}$, which contains a population of cells positive for GLYT2 mRNA. Another example may be the facial nucleus that was unlabeled for GLYT2 mRNA but contains high levels of protein that probably derives from glycinergic neurons located in the surrounding areas.

The expression of GLYTl is more restricted than that of GLYT1 mRNA. For GLYT1, an important discrepancy between the distribution of protein and mRNA remains to be solved. In situ hybridization experiments have shown, that although part of the mRNA expression could be glial (and the data in the present report confirm this point), a very high expression of GLYT1 mRNA occurs in neurons, both in caudal and rostral regions of the CNS (Smith et al., 1992; Borowsky et al., 1993; Zafra, Gomeza, Olivares, Aragón, and Giménez, unpublished observations). Thus, from in situ hybridization data, the existence of a neuronal form of GLYTl has to be inferred. However, our antibodies failed to detect this form of the protein. Several explanations could be given for this fact. For instance, three isoforms of GLYT1 (GLYT1a, GLYT1b, and GLYT1c) have been described (Borowsky et al., 1993, Kim et al., 1994; Adams et al., 1995). Although the antibodies used in the present study have been raised against a sequence common to all the three isoforms, it could well be that the neuronal isoform undergoes a different posttranslational processing than the glial one, possibly becoming undetectable by the antibodies. Two experimental observa- tions support this possibility. First, it has been reported that the mRNA for the isoform GLYTlb is enriched in white matter, suggesting a glial localization, whereas the isoform GLYT1a is concentrated in the gray matter (probably on neurons), but is also expressed in peripheral tissues (Borowsky et al., 1993). The fact that our antibodies failed to detect GLYTI in peripheral tissue by Western blots indicates that the isoform GLYTla is not recognized by these antibodies. Second, we have observed a weak cytoplasmic staining in the neurons. The regional distribution of this cytoplasmic staining matches quite precisely the in situ data. Thus, neurons with a higher contents of GLYT1 mRNA show a higher cytoplasmic staining for GLYT1 protein. This is consistent with the view that the antibody is detecting nascent forms of the protein, but after processing, the epitopes recognized by the antibodies are not accessible any longer. One alternative possibility to explain the discrepancy between the cellular localizations of the mRNA and the protein could be the existence of additional unidentified isoforms differing in the carboxyl terminus. These different possibilities are being further investigated. Interestingly, in spite of the above described discrepancy, those regions of the diencephalon, the brainstem (for example, facial and pontine nuclei), the spinal cord, and the cerebellum expressing high levels of neuronal GLYT1 mRNA are the same areas where we have now found high levels of glial protein, suggesting the existence of regional clues that cause the GLYT1 gene to be expressed both in the neurons and in the glia of these particular regions. One attractive possibility is the existence of a regulatory cross-talk between neurons and glia. In fact experimental evidence for such cross-talk has been obtained for the regulation of the expression of glutamate transporters in glial cells. Thus, a downregulation of glial glutamate transporter has been reported in the striatum after destruction of the glutamatergic corticostriatal projections (Levy et al. 1993)

\section{GLYTI could have additional functions}

Previous studies at the mRNA level have shown a relatively high expression of GLYTl mRNA in forebrain regions such as the cortex, the hippocampus (Smith et al, 1992; Borowsky et al., 1993; Zafra, Gomeza, Olivares, Aragón, and Giménez, unpublished observations), or the olfactory bulb (Guastella et al., 1992), where no inhibitory glycinergic neurons have been found, thus suggesting additional roles for GLYT1. Data included in the present article reinforce this suggestion, as also the GLYT1 protein has been found in areas devoid of inhibitory glycinergic neurotransmission. Examples of these regions are the molecular layer of the cerebellum, the thalamus, the hypothalamus or, in a lesser extent, the olfactory bulb, the cortex, and the hippocampus. Also, in caudal areas of the CNS such as the pontine nucleus, the inferior olive, the tegmental nuclei, or the MNTB among others, the levels of GLYTI are high, whereas those of the strychnine-sensitive glycine receptor are low or moderate. It has been suggested that one of these additional roles could be the regulation of glycine levels in NMDA receptor-mediated neurotransmission (Smith et al., 1992). However, the levels of GLYT1 in areas rich in NMDA receptors such as the corpus striatum, the hippocampus, or the cortex are rather low. Nevertheless, as discussed above, the GLYT1 mRNA distribution suggests the existence of a neuronal form of the protein that at the moment has not been detected at the protein level. Thus, it cannot be excluded that such a hypothetical neuronal GLYT1 could be associated with the NMDA receptor-mediated glutamatergic neurotransmission. Other possibilities exist, such as association 
with non-strychnine-sensitive glycine receptors. In this respect, the distribution of the mRNA for the $\beta$-subunit of the glycine receptor (Malosio et al.,1991) shows similarities with that of GLYT1 mRNA (Borowski et al., 1993). Additional experimental work is necessary to solve this important issue.

In summary, we have described the regional and cellular localization of two glycine transporters, supporting the view that both of them arc involved in glycinergic neurotransmission. One of them, GLYT2, has been localized in presynaptic elements of synapses thought to be glycinergic, whereas the other one, GLYT1, has been detected in the delicate processes of glial elements that surround both glycinergic and nonglycinergic terminals.

\section{References}

Adams RH, Sato K, Shimada S, Tohyama M, Püschel AW, Betz H (1995) Gene structure and glial expression of the glycine transporter GLYT1 in embryonic and adult rodents. J Neurosci 15: in press.

Amara SG, Kuhar MJ (1993) Neurotransmitter transporters: recent progress. Annu Rev Neurosci 16:73-93.

Aoki E, Semba R, Keino H, Kato K, Kashiwamata S (1988) Glycinelike immunoreactivity in the rat auditory pathway. Brain Res 442: 63-71.

Araki T, Yamano M, Murakami T, Wanaka A, Betz H, Toyama M (1988) Localization of glycine receptor in the rat central nervous system: an immunocytochemical analysis using monoclonal antibody. Neuroscience 25:613-624.

Blakely RD, Berson HE, Fremau RT, Caron MG, Peek MM, Prince HK, Bradley CC (1991) Cloning and expression of a functional serotonin transporter from rat brain. Nature 354:66-70.

Borden LA, Smith KE, Hartig PR, Branchek TA, Weinshank RL (1992) Molecular heterogeneity of the $\gamma$-aminobutyric acid (GABA) transport system. J Biol Chem 267:21098-21104.

Borowsky B, Mezey E, IIoffman BJ (1993) Two glycine transporters variants with distinct localization in the CNS and peripheral tissues are encoded by a common gene. Neuron 10:851-863.

Bruun A, Ehinger B (1974) Uptake of certain possible neurotransmitters into retinal neurons of some mammals. Exp Eye Res 19:435447.

Crooks J, Kolb H (1992) Localization of GABA, glycine, glutamate and tyrosine hydroxylase in the human retina. J Comp Neurol 315 : $287-302$.

Danbolt NC, Pines G, Kanner BI (1990) Purification and reconstitution of the sodium- and potassium-coupled glutamate transport glycoprotein from rat brain. Biochemistry 29:6734-6740.

Davanger S, Ottersen OP, Storm-Mathisen J (1991) Glutamate, GABA, and glycine in the human retina: an immunocytochemical investigation. J Comp Ncurol 311:483-494.

Fedele E, Foster, AC (1992) [ $\left.{ }^{3} \mathrm{H}\right]$ Glycine uptake in rat hippocampus: kinetic analysis and autoradiographic localization. Brain Res 572: 154-163.

Fremau RT, Caron MG, Blakely R (1992) Molecular cloning and expression of high-affinity L-proline transporter expressed in putative glutamatergic pathways of rat brain. Neuron 8:915-926.

Giros B, Mestikawy SE, Bertrand L, Caron MG (1991) Cloning and functional characterization of a cocaine-sensitive dopamine transporter. FEBS Lett 295:149-154

Glendenning KK, Baker BN (1988) Neuroanatomical distribution of receptors for three potential inhibitory neurotransmitters in the brain stem auditory nuclei of the cat. J Comp Neurol 275:288-308.

Grünert U, Wässle H (1993) Immunocytochemical localization of glycine receptors in the mammalian retina. J Comp Neurol 335:523537.

Guastella J, Nelson N, Nelson H, Czyzyk L, Keynan S, Miedel M, Davidson N, Lester HA, Kanner BI (1990) Cloning and expression of a rat brain GABA transporter. Science 249:1303-1306.

Guastella J, Brecha N, Weigmann C, Lester HA, Davidson N (1992) Cloning, expression, and localization of a rat brain high-affinity glycine transporter. Proc Natl Acad Sci USA 89:7189-7193.

Helfert RH, Bonneau JM, Wenthold RJ, Altschuler RA (1989) GABA and glycine immunoreactivity in the guinea pig superior olivary complex. Brain Res 501:269-286.
Hoffman BJ, Mezey E, Brownstein MJ (1991) Cloning of a serotonin transporter affected by antidepressants. Science 254:579-580.

Holopainen I, Kontro P (1989) Uptake and release of glycine in cercbellar granulc cclls and astrocytes in primary culture: potassiumstimulated release from granule cells is calcium-dependent. J Neurosci Res 24:374-383.

Jenkins WM, Masterton RB (1982) Sound localization: effects of unilateral lesions in the central auditory system. J Neurophysiol 47:9871016.

Johnson JW, Ascher P (1987) Glycine potentiates the NMDA response in cultured mouse brain neurons. Nature 325:529-531.

Johnston GAR, Iversen LL (1971) Glycine uptake in rat central nervous system slices and homogenates: evidence for different uptake systems in spinal cord and cerebral cortex. J Neurochem 18:19511961

Kanai Y, Hediger MA (1992) Primary structure and functional characterization of a high-affinity glutamate transporter. Nature 360:467471

Kanai Y, Smith P, Hediger MA (1994) A new family of neurotransmitter transporters: the high-affinity glutamate transporters. FASEB J $8: 1450-1459$.

Kanner BI, Schuldiner S (1987) Mechanism of transport and storage of neurotransmitters. CRC Crit Rev Biochem 22:1-38.

Kilty JE, Lorang D, Amara SG (1991) Cloning and expression of a cocaine-sensitive rat dopamine transporter. Science 254:578-579.

Kim KM, Kingsmore SF, Han H, Yang-Feng TL, Godinot N, Seldin MF, Caron MG, Giros B (1994) Cloning of the human glycine transporter type 1: molecular and pharmacological characterization of novel isoform variants and chromosomal localization of the gene in the human and mouse genomes. Mol Pharmacol 45:608-617.

Kolston J, Osen KK, Hackney CM, Ottersen OP, Storm-Mathisen J (1992) An atlas of glycine- and GABA-like immunoreactivity and colocalization in the cochlear nuclear complex of the guinea pig. Anat Embryol 186:443-465.

Kuhar MJ, Zarbin MA (1978) Synaptosomal transport: a chloride dependence for choline, GABA, glycine and several other compounds. J Neurochem 31:251-256.

Langosch D, Becker CM, Betz H (1990) The inhibitory glycine receptor: a ligand-gated channel of the central nervous system. Eur J Biochem 194:1-8

Lehre KP, Levy LM, Ottersen OP, Storm-Mathisen J, Danbolt NC (1995) Differential expression of two glial transporters in the rat brain: quantitative and immunocytochemical observations. J Neurosci 15: in press.

Levy LM, Lehre KP, Walaas I, Storm-Mathisen J, Danbolt NC (1993) Down regulation of a glial glutamate transporter in striatum after destruction of the glutamatergic corticostriatal projection. J Neurochem 61:S208

Liu QR, Mandiyan S, Nelson H, Nelson N (1992) A family of genes encoding neurotransmitter transporters. Proc Natl Acad Sci USA 89 6639-6643.

Liu QR, López-Corcuera B, Mandiyan S, Nelson H, Nelson N (1993) Cloning and expression of a spinal cord- and brain-specific glycine transporter with novel structure features. J Biol Chem 268:2280222808.

Logan WJ, Snyder SH (1972) High affinity uptake systems for glycine, glutamic and aspartic acids in synaptosomes of rat central nervous tissues. Brain Res 42:413-431.

López-Corcuera B, Vázquez J, Aragón C (1991) Purification of the sodium- and chloride-coupled glycine transporter from central nervous system. J Biol Chem 266:24809-24814.

Lowry OH, Rosehrough NJ, Farr AL, Randall RJ (1951) Protein measurement with the Folin phenol reagent. J Biol Chem 193:265-275.

Malosio ML, Marqueze-Pouey B, Kuhse J, Betz H (1991) Widespread expression of glycine receptor subunit mRNAs in the adult and developing rat brain. EMBO J 10:2401-2409.

Massey SC, Miller RF (1990) N-methyl-D-aspartate receptors of ganglion cells in rabbit retina. J Neurophysiol 63:16-30.

Moore MJ, Caspary DM (1983) Strychnine blocks binaural inhibition in lateral superior olivary neurons. $J$ Neurosci 3:237-242.

Olivares L, Aragón C, Giménez C, Zafra F (1994) Carboxyl terminus of glycine transporter GLYT1 is necessary for correct processing of the protein. J Biol Chem 269:28400-28404.

Ottersen OP, Davanger S, Storm-Mathisen J (1987) Glycine-like immunoreactivity in the cerebellum of rat and Senegalese baboon, $\mathrm{Pa}$ - 
pio papio: a comparison with the distribution of GABA-like immunoreactivity and with $\left[{ }^{3} \mathrm{H}\right]$ glycine and $\left[{ }^{3} \mathrm{H}\right] \mathrm{GABA}$ uptake. Exp Brain Res 66:211-221.

Ottersen OP, Storm-Mathisen J, Somogyi P (1988) Co-localization of glycine-like and GABA-like immunoreactivities in Golgi terminals in the rat cerebellum: a postembedding light and electron microscopic study. Brain Res 45:342-353.

Ottersen OP, Storm-Mathisen J, Laake JH (1990) Cellular and subcellular localization of glycine studied by quantitative electron microscopic immunocytochemistry. In: Glycine neurotransmission (Ottersen OP, Storm-Mathisen J, eds), pp 303-328. Chichester: Wiley.

Pacholczyk T, Blakely RD, Amara S (1991) Expression cloning of a cocaine and antidepressant-sensitive human noradrenaline transporter. Nature 350:350-354.

Palay SL, Chan-Palay V (1974) Cerebellar cortex: cytology and organization. Berlin: Springer.

Paxinos G, Watson C (1982) The rat brain stereotaxic coordinates. Sydney: Academic.

Pines G, Danbolt NC, Bjoras M, Zhang Y, Bendahan A, Eide L, Koepsell H, Storm-Mathisen J, Seeberg F, Kanner BI (1992) Cloning and expression of a rat brain L-glutamate transporter. Nature 360:464467.

Pourcho RG, Goebel DJ (1985) A combined Golgi and autoradiographic study of $\left[{ }^{3} \mathrm{H}\right]$ glycine-accumulating amacrine cells in the cat retina. J Comp Neurol 233:473-480.

Pourcho RG, Goebel DJ (1987) Visualization of endogenous glycine in cat retina: an immunocytochemical study with Fab fragments. J Neurosci 7:1189-1197.

Radian R, Bendahan A, Kanner BI (1986) Purification and identification of the functional sodium- and chloride-coupled $\gamma$-aminobutyric acid transport glycoprotein from rat brain. J Biol Chem 261:1543715441.

Sanes DH (1990) An in vitro analysis of sound localization mechanisms in the gerbil lateral superior olive. J Neurosci 10:3494-3506.

Sanes DH, Geary WA. Wooten GF, Rubel EW (1987) Quantitative distribution of the glycine receptor in the auditory brain stem of the gerbil. J Neurusci 7:3793-3802.

Sato K, Yoshida S, Fujiwara K, Tada K, Tohyama M (1991) Glycine cleavage system in astrocytes. Brain Res 567:64-70.

Schwartz IR (1985) Autoradiographic studies of amino acids labeling of neural elements in the auditory brain stem. In: Auditory biochemistry (Drescher DG, ed), pp 258-277. Springfield, MA: Thomas.

Schwartz IR, Ryan AF (1986) Amino acid labeling patterns in the efferent innervation of the cochlea: an electron microscopy autoradiographic study. J Comp Neurol 246:500-512.

Shimada S, Kitayama S, Lin C, Patel A, Nanthakumar E, Geagor P, Kuhar M, Uhl G (1991) Cloning and expression of a cocaine-sen- sitive dopamine transporter complementary DNA. Science 254:576578

Smith KE, Borden LA, Harting PR, Branchek T, Weinshank RL (1992) Cloning and expression of a glycine transporter reveal co-localization with NMDA receptors. Neuron 8:927-935.

Somogyi P, Takagi H (1982) A note on the use of picric acid-paraformaldehyde-glutaraldehyde fixative for correlated light and electron microscopic immunocytochemistry. Neuroscience 7:1779-1783.

Spirou G, Brownell WE, Zidanic M (1990) Recordings from cat trapezoid body and HRP labeling of globular bushy cell axons. J Neurophysiol 63:1169-1190.

Stefanini M, De Martino C, Zamboni L (1967) Fixation of ejaculated spermatozoa for electron microscopy. Nature 216:173-174.

Storck T, Schulte S, Hofmann K, Stoffel W (1992) Structure, expression, and functional analysis of a $\mathrm{Na}^{+}$-dependent glutamate/aspartate transporter from rat brain. Proc Natl Acad Sci USA 89:10955-10959.

Uhl GR, Hartig PR (1992) Transporter explosion: update on uptake. Trends Pharmacol Sci 13:421-425.

Usdin TB, Mezey E, Chen C, Brownstein MJ, Hoffmann BJ (1991) Cloning of the cocaine-sensitive bovine dopamine transporter. Proc Natl Acad Sci USA 88:8230-8234.

Van den Pol AN, Gorcs T (1988) Glycine and glycine receptor immunoreactivity in brain and spinal cord. J Neurosci 8:472-492.

Warr WB (1966) Fiber degeneration following lesions in the anterior ventral cochlear nucleus of the cat. Exp Neurol 14:453-474.

Wenthold RJ, Huie D, Altschuler RA, Reeks KA (1987) Glycine immunoreactivity localized in the cochlear nucleus and superior olivary complex. Neuroscience 2:897-912.

Wenthold RJ, Parakkal MH, Oberdorfer MD, Altschuler RA (1988) Glycine receptor immunoreactivity in the ventral cochlear nucleus of the guinea pig. J Comp Neurol 276:423-435.

Wickesberg RE, Whitlon D, Oertel D (1991) Tuberculoventral neurons project to the multipolar cell area but not to the octopus cell area of the posteroventral cochlear nucleus. J Comp Neurol 313:457-468.

Wilkin GP, Csillag A, Balázs R, Kingsbury AE, Wilson JE, Johnson AL (1981) Localization of high affinity $\left[{ }^{3} \mathrm{H}\right]$ glycine transport sites in the cerebellar cortex. Brain Res 216:11-33.

Wu SH, Kelly JB (1991) Physiological properties of neurons in the mouse superior olive: membrane characteristics and postsynaptic responses studied in vitro. J Neurophysiol 65:230-246.

Zafra F, Giménez C (1986) Characterization of glycine uptake in plasma membrane vesicles isolated from cultured glioblastoma cells. Brain Res 397:108-116.

Zafra F, Giménez C (1989) Characteristics and adaptive regulation of glycine transport in cultured glial cells. Biochem J 258:403-408.

Zarbin MA, Wamsley JK, Kuhar MJ (1981) Glycine receptor: light microscopy autoradiographic localization with $\left[{ }^{3} \mathrm{H}\right]$ strychnine. J Neurosci $1: 532-547$. 